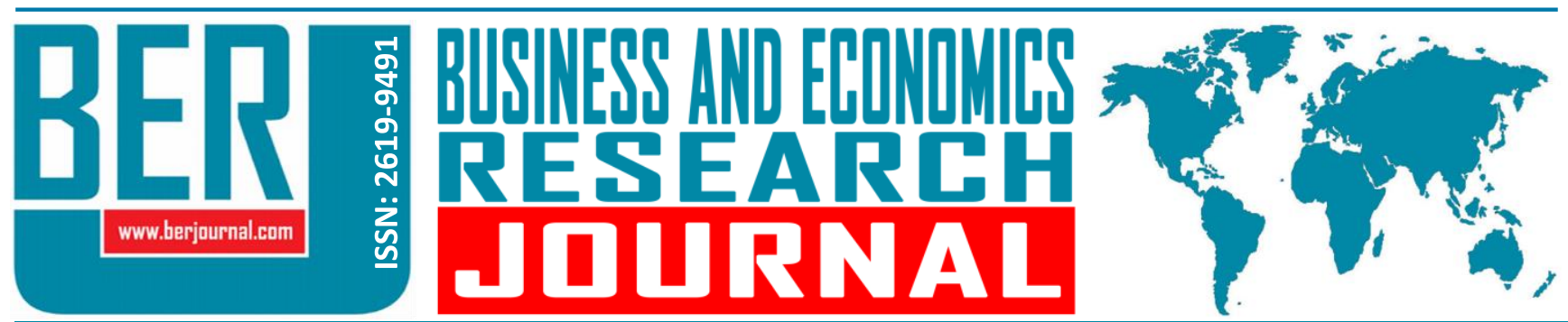

Business and Economics Research Journal Vol. 9, No. 4, 2018, pp. 923-943 doi: 10.20409/berj.2018.148

\title{
Mobil Uygulama Reklam Türlerinin Reklama Yönelik Tutum ve Reklam Kabulüne Etkisi
}

\author{
Mutlu Yuksel Avcilar ${ }^{\mathrm{a}}$, Banu Kulter Demirgunes ${ }^{\mathrm{b}}$, Gulhan Yenilmez
}

Öz: Akıllı telefonların kullanımının yaygınlaşmasının sonucu olarak uygulama içi mobil reklamların kullanım düzeyi artmıştır. Uygulama içi mobil reklamların etkin bir şekilde kullanılabilmesi için tüketicilerin uygulama içi reklamlara yönelik tutum, mobil reklamlardan algıladıkları değer ve uygulama içi mobil reklamları kabul etme düzeylerini etkileyen faktörleri tespit etmek oldukça önemlidir. Bu çalışmada, mobil reklam kabulünü etkileyebilecek faktörler, üç ayrı mobil reklam türü için değerlendirilmektedir. Çalışmanın amacı, mobil uygulamalara gelen reklam türlerinin; reklama yönelik tutum, reklamdan algılanan değer ve reklamın kabulü üzerindeki etkilerini tespit etmektir. Araştırma için gerekli olan veriler, Ankara'da yaşayan 550 akıllı telefon kullanııısından, kolayda örnekleme yöntemi ve yüz yüze anket yöntemi ile elde edilmiştir. Değişkenler arasındaki ilişkileri tespit etmek için hiyerarşik regresyon analizi kullanılmıștır. Analizler sonucunda, tutum ve reklamdan algılanan değerin, mobil reklamı kabullenmeyi olumlu yönde etkilediği tespit edilmiştir. Ayrıca analiz sonucunda, reklamın içerik özelliklerinden etkileşimlilik, eğlence ve güvenilirliğin, tutum üzerinde en etkili faktörler oldukları; algılanan değer üzerinde en etkili faktörün ise tutum olduğu tespit edilmiştir. Analizler sonucunda, tutumun algılanan değer üzerinde en yüksek etkiye sahip olduğu reklam türünün banner reklam olduğu ortaya konulmuştur. Mobil reklam değerinin, mobil reklam kabulü üzerinde en yüksek etkiye sahip olduğu reklam türünün ise etkileşimli geçiş (video) reklamları olduğu tespit edilmiştir.

\author{
Anahtar Sözcükler: Mobil \\ Reklam, Mobil Reklama \\ Yönelik Tutum, Mobil \\ Reklamın Algılanan Değeri, \\ Mobil Reklam Türleri, Mobil \\ Reklam Kabulü
}

JEL: M30, M31, M37

$\begin{array}{ll}\text { Geliş } & : 06 \text { Mart } 2018 \\ \text { Düzeltme } & :-- \\ \text { Kabul } & : 16 \text { Mayıs } 2018 \\ \text { Tür } & \text { : Araştırma }\end{array}$

\section{The Effects of In-App Mobile Ads Types on The Attitude Towards and Acceptance of Ads}

\begin{abstract}
The widespread use of smartphones has increased the level of usage of in-app mobile ads. In order to use in-app mobile ads effectively, it is important to identify the consumers' attitudes towards in-app ads, the value they perceive in-app ads and the factors that might affect the level of acceptance of the in-app mobile ads. This study tests the factors affecting mobile advertising acceptance for three different mobile advertising types. Therefore, the purpose of this study is to determine the effects of the in-app mobile ads on the attitude toward in-app mobile ads, the value they perceive, and acceptance of in-app mobile ads. The data were collected from the 550 smartphone users living in Ankara by using convenience sampling and face-to-face survey method. Hierarchical regression analysis was used to test the relations among variables. Analysis results revealed that the attitude towards and value perceived from in-app mobile advertisements have positive effects on the acceptance of in-app mobile advertising. Besides, analysis results revealed that interactivity, entertainment, and reliability are the most effective factors on the attitude and the most effective factor on the perceived value is the attitude. Moreover, analysis results indicated that for the banner ads the attitude has the highest impact on the perceived value. Finally, it is found that perceived ads value has the highest impact on the acceptance of in-app mobile advertising for the interactive transition (video) ads.
\end{abstract}

Keywords: Mobile Ad, Attitude Towards Mobile Ad, Perceived Value of Mobile Ad, Types of Mobile Ad, Accepting Mobile Ad

\section{JEL: M30, M31, M37}

\section{Received : 06 March 2018 \\ Revised :-- \\ Accepted : 16 May 2018}

Type : Research

Asst. Prof., PhD., Osmaniye Korkut Ata University, Faculty of Economics and Administrative Sciences, Department of Management Information Systems, Osmaniye, Turkiye, myukselavcilar@osmaniye.edu.tr (ORCID ID: 0000-0001-5621-2377)

b Asst. Prof., PhD., Ahi Evran University, Faculty of Economics and Administrative Sciences, Department of Business Administration, Kirsehir, Turkiye, banu.kulter@ahievran.edu.tr (ORCID ID: 0000-0002-9511-2069) Res. Asst., Osmaniye Korkut Ata University, Faculty of Economics and Administrative Sciences, Department of Business Administration, Osmaniye, Turkiye, gulhanyenilmez@osmaniye.edu.tr (ORCID ID:0000-0002-6570-6448) 


\section{Giriş}

Günümüzün en etkili bilgi edinme, iletişim kurma, eğlenme ve sosyalleşme aracı akıllı telefonlardır. Social ve Hootsuite firması tarafından 2017 yılında yayınlanan dijital araştırma raporunda, dünya nüfusunun yarısından fazlasının (\%66'sının) -4,92 milyar kişi- akıllı telefon sahibi olduğu belirtilmektedir. Pew Araştırma Merkezi'nin Şubat 2016 'da yayınladığı rapora göre ise, akıllı telefona sahip olma oranının yüksek olduğu ülkeler arasında \%88 ile Güney Kore, \%77 ile Avustralya, \%74 ile İsrail, \%72 ile Amerika ve \%71 ile İspanya gelmektedir. Akıllı telefona sahip olma durumunda Türkiye \%59 ile dünya genelinde 12 . sırada yer almaktadır. TÜiK'in Nisan 2016 yılı verilerine göre; Türkiye'deki hanelerin \%96,9'unda cep telefonu ya da akıllı telefon bulunmaktadır.

Bilgisayarların yapabildiği birçok işlemi yapabilen akıllı telefonların görüntü, ses kaydı, mobil internet bağlantısı gibi özellikleri bulunmaktadır. Akıllı telefonların en önemli özelliklerinden biri de pazarlama amaçları için kullanılabilmeleridir. Akıllı telefonların her yerde bulunabilme, geniş çapta interaktif uygulamalara imkân verme ve yüksek kişiselleştirilebilme gibi özellikleri, bu telefonları e-pazarlama için uygun bir araç haline getirmektedir. Reklamcılar Derneği Mart 2017 raporuna göre, Türkiye'de toplam reklam yatırımlarının 7.183 milyon TL düzeyinde olduğu, mobil reklam yatırımlarının ise 135,74 milyon TL düzeyinde olduğu tahmin edilmektedir.

Mobil reklamcılık kavramı, akıllı telefonların reklam aracı olarak kullanılmasıyla birlikte ortaya çıkmıştır (Barutçu ve Göl, 2009:26). Mobil reklamcılık, mobil cihazlar aracılığıyla tanıtım amaçlı olarak ürünler, hizmetler ve görüşler ile ilgili olan bir mesajın iletilmesidir (Li ve Stoller, 2007:5). Mobil reklamcılığın bir türü olan uygulama içi mobil reklamlar, mobil uygulamalarla görüntülenen reklamlar olarak tanımlanabilmektedir (Hallgrímsson, 2016:13). Uygulama içi mobil reklamlar, bir dizi banner, etkileşimli geçiş (video), tıklayıncabüyüyen reklamlar veya tıkla indir uygulama reklamları aracılığıyla görüntülenebilmektedirler (Bhave, Jain ve Roy, 2013:64). İnternet reklamcılığına daha çok benzeyen ve akıllı telefonlarda yer alan uygulamalara gelen mobil reklamlar, interaktif ve multimedya özellikleri göz önüne alındığında, tüketicilere mümkün olduğunca daha zengin bir deneyim sunmaktadır (Raines, 2013:126).

Uygulama içi mobil reklamlar, işletmelere kendi mobil uygulamalarıyla doğrudan tüketicileri hedefleyebilme imkânı sunmaktadır (Raines, 2013:126). Hedef kitle, potansiyel olarak uygulamalarda günde ortalama iki saatini harcayan tüketici kesiminden oluşmaktadır (Raines, 2013:126). Interaktif Reklamcllık Bürosu (Interactive Advertising Bureau-IAB)'nun Mayıs 2017'de yaptığı araştırmada, dünya genelindeki akıllı telefon kullanıcılarının \%47'sinin, mobil bir uygulamada reklam gördükten sonra reklamla ilgili daha fazla bilgi edinmek için eyleme geçtikleri tespit edilmiştir. Aynı araştırmada akıllı telefon kullanııılarının \%86'sının, akıllı telefonlarda yer alan uygulamalara gelen mobil reklamları görüntüledikten sonraki ilk birkaç gün içerisinde bu reklamları hatırladıkları, kullanıcıların \%13'ünün uygulamalara gelen mobil reklamları tıkladıkları, \%9'unun ise mobil reklamları gördükten sonra markanın web sitesini ziyaret ettikleri tespit edilmiştir (Monica, 2017).

Akıllı telefon aracılığıyla gerçekleştirilen iletişim, tüketiciler sürekli olarak akıllı telefonlarda yer alan uygulamaları kullandığı ve bu uygulamalarda gördükleri reklamı benimseyip etkileşime geçtikleri sürece etkili olacaktır. Bu nedenle, tüketicilerin akıllı telefonlarda yer alan uygulamalara gelen mobil reklamları benimsemesi ve kabullenmesinde hangi faktörlerin etkili olduğunun bilinmesi oldukça önemlidir.

Konuyla ilgili literatür incelendiğinde, tüketicilerin mobil reklamlara karşı tutumlarını inceleyen çalışmaların (Haghirian, Madlberger ve Inoue, 2008; Lee ve Hsieh, 2009; Ünal, Ercis ve Keser, 2011; Saadeghvaziri ve Hosseini, 2011) oldukça fazla sayıda olduğu görülmektedir. Bir kısım araştırmacılar, mobil reklamı tutum, niyet ve davranış kapsamında incelerlerken (Tsang, Ho ve Liang, 2004; Ünal vd., 2011); bir kısım araştırmacılar (Haghirian vd., 2008; Kim ve Han, 2014; Demirgüneş ve Avcılar, 2016) mobil reklamı akış deneyimi ve reklamın değeri gibi değişkenler kapsamında incelemektedirler. Ancak, mobil uygulamalarda gösterilen reklamlar araştırmacılar arasında özellikle sınırlı bir ilgi görmüştür (Bhave vd., 2013; Raines, 2013; Nielsen, 2015; Hallgrimsson, 2016). Mobil uygulamaların öneminin artmasına rağmen mobil reklamlar ile ilgili yapılan araştırmalar, çoğunlukla SMS ve MMS reklamları gibi daha eski formatlar üzerinde yoğunlaşmıştır (Tsang vd., 2004; Moynihan, Kabadayi ve Kaiser, 2010; Watson, McCarthy ve Rowley, 2013). Önceki çalışmalarda karşılaşılan bir diğer kısıt ise, erişilebilirlik ve düşük maliyet nedeniyle, çalışmaların çoğunda 
yalnızca örneklem olarak lise ve/veya üniversite öğrencilerinin kullanılmasıdır (Choi, Hwang ve McMillan, 2008; Liu vd., 2012; Parreño vd., 2013). Oysaki, üniversite öğrencileri ile genel nüfus arasında önemli bir farklılık olabileceğinden, araştırmanın dışsal geçerliliğini arttırmak için daha farklı mobil tüketici profilinden oluşan örneklemlerin kullanılması önerilmektedir (Hallgrímsson, 2016:9).

Bu çalışmada, akıllı telefonlarda yer alan uygulamalara gelen mobil reklam türlerinin, reklama yönelik tutum ve reklam kabulü üzerindeki etkileri konu alınmaktadır. Çalışmanın amacı; tüketicilerin mobil reklamların içeriğine yönelik algılarının, 1) mobil reklamlara yönelik tutumları, 2) mobil reklamlardan algıladıkları değer ve 3) mobil reklamları kabullenmeleri üzerindeki etkilerini tespit etmektir. Çalışma, tüketicilerin banner, interstitial (tam sayfa) ve etkileşimli geçiş (video) türündeki mobil reklam mesajlarına yönelik algılarını kapsamaktadır.

Bu çalışmada, akıllı telefonlarda yer alan uygulamalara gelen mobil reklam türlerinin, mobil reklamlara yönelik tutumun, mobil reklamdan algılanan değerin konu alınmasının ve söz konusu kavramların mobil reklamları kabullenme kapsamında değerlendirilmesinin literatüre katkı sağlayacağı düşünülmektedir. Bunun yanında çalışmanın sonuçları, tüketicilerin mobil reklamları kabullenmeleri üzerinde etkili olan faktörleri değerlendirmeleri ve buna uygun reklam stratejileri geliştirmeleri yönünde işletmelere yol gösterebilecektir. Nitekim çalışmada reklam türlerine yönelik tutumların ve algılanan değerin, nasıl attırılabileceği konusunda işletmelere önerilerde bulunulmaktadır.

\section{Literatür İncelemesi}

\subsection{Mobil Reklam}

Genel olarak mobil reklamcılık, bir mobil cihaz aracılığıyla reklam yayınlanması olarak tanımlanmaktadır (Yang, 2007:33). Mobil Pazarlama Derneği (2016) ise, mobil reklamı, bir mobil cihaz aracılığıyla tüketici ile iletişim kurulan reklam biçimi olarak tanımlamaktadır.

Literatürde mobil reklam, genellikle itme ve çekme reklam olarak iki türde tartışımaktadır (Barnes, 2002; Scharl, Dickinger ve Murphy, 2005; Barutçu ve Öztürk, 2009; Ünal vd., 2011; Raines, 2013). Söz konusu iki tür arasındaki fark ise erişim şekliyle ilgilidir. İtme reklamlar, pazarlamacının bir mesajı tüketiciye aktif olarak ittiği (rastgele gönderdiği) reklam türüdür (Raines, 2013:126). İtme reklamlarda tüketici ve pazarlamacı arasındaki iletişim, pazarlamacı tarafından, tüketici talebi olmadan ve genellikle izinsiz olarak başlatılmaktadır (Barnes, 2002:406; Yang, Kim ve Yoo, 2013:1345). Tüketici bu durumda pazarlamacıdan aldığı reklam ve promosyon sıklığı konusunda genellikle çok az kontrol sahibidir (Constantinescu ve Tanasescu, 2014:79). Ancak istenmeyen mesajlar, alııının rahatsız olmasına ve alıııda markaya karşı olumsuz tutumlara neden olabilecek bir müdahale hissi uyandırmasına neden olabilmektedir (Hallgrímsson, 2016:17).

Çekme reklamlar, tüketicinin gönüllü olarak reklam içeriğini 'çektiği' (pazarlamacının mesajı göndermek için mobil kullanıcıların gönüllü olarak kendilerine mesaj göndermesini beklediği) reklamlardır (Raines, 2013:127). Bu reklamlarda genellikle reklamlar gönderilmeden önce tüketicilerin izni istenmekte ve iletişim, reklam veren yerine tüketici kaynaklı olarak gerçekleşmektedir (Unni ve Harmon, 2007: 30). Bu tür reklamlarda, müşteriler reklamı açıp açmamayı seçebildiklerinden bu reklamlar, müşterilere daha fazla güç vermektedir (Hallgrímsson, 2016: 17).

Mobil reklamcılı̆ı̆ başarısı, tüketicinin reklamı kabullenmesine bağlıdır. Tüketicilerin reklama yönelik tutumu başlangıçta olumsuz olsa dahi reklam mesajının içeriği, tüketicinin ilgisini çekerse tüketiciler reklamı kabul etme niyetinde olabileceklerdir (Bauer vd., 2005:182). Mobil reklamın içeriği farklı boyutlardan oluşmaktadır. Bilgilendirme, eğlence, rahatsız etme, güvenilirlik, teşvik etme, kişiselleştirme ve etkileşimlilik reklamın içeriğini değerlendirmede en sık kullanılan faktörlerdir (Ducoffe, 1996; Tsang vd., 2004; Haghirian ve Madlberger, 2008; Zabadi, Shura ve Elsayed, 2012; Raines, 2013; Demirgüneş ve Avcılar, 2016; Hallgrimsson, 2016). Bununla birlikte, literatürde demografik değişkenler (Haghirian ve Madlberger, 2008; Raines, 2013; Hallgrimsson, 2016); tüketiciden izin alma (Tsang vd., 2004; Carroll vd., 2007; Ünal vd., 2011); mobil telefon kullanma yeteneği (Lee ve Hsieh, 2009); mobil uygulama kullanımı (Avery, 2016) ve reklam mesajı alma sıklığı (Sabokwigina, Malima ve Mpogole, 2013) gibi faktörler de mobil reklam kapsamında 
değerlendirilebilmektedir. Çalışmaların bir kısmında mobil reklamcılığa yönelik tutum ve niyetin, genel olarak olumsuz olduğu vurgulanmaktadır (Tsang vd., 2004; Wong ve Tang, 2008).

Bilgilendirme ve eğlence faktörleri, tutum oluşumunda ana faktörler olarak gösterilmektedir (Okazaki, 2004; Bauer vd., 2005; Wong ve Tang, 2008). Bracket ve Carr (2001)'ın bütünleşik web reklamcılığı çalışmasında yer alan güvenilirliğin de tutumları etkileyen önemli bir faktör olduğu tespit edilmiştir (Bracket ve Carr, 2001; Chowdhury vd., 2006; Okozaki, Katsura ve Nishiyama, 2007; Ünal vd., 2011; Liu vd., 2012). Kişiselleştirme (Jun ve Lee, 2007; Xu, 2007; Choi vd., 2008), teşvik etme (Tsang vd., 2004; Ünal vd., 2011; Nabus ve Hussin, 2015; Demirgüneş ve Avcılar, 2016) ve etkileşiminde (Raines, 2013) tutum üzerinde önemli etkilerinin olduğu belirlenmiştir. Buna karşılık, rahatsız etme faktörünün tüketicinin genel tavrını olumsuz yönde etkilediği tespit edilmiştir (Tsang vd., 2004; Choi vd., 2008).

Bilgilendirme, reklamların ürün ve alternatifleriyle ilgili güncellenmiş, zamanında ve kolayca erişilebilir bilgi sunma yeteneğidir (Ducoffe, 1996: 22). Tüketiciler, talep ettikleri doğru bilgiye kolay ve hızlı bir şekilde erişebilmek istemektedirler (Nabus ve Hussin, 2015:5). Bu nedenle, mobil cihazlar aracilı̆ıyla tüketicilere gönderilen bilgilerin doğru olması, zamanında gönderilmesi ve tüketicilere fayda sağlaması gerekmektedir (Xu, 2007: 11). Bilgilendirme, tüketicilerin reklamı kabul etmelerinde temel bir faktör olarak görülmektedir. Sandage vd. (1989), reklamcılığın bilgi verme rolünün, reklamları kabul etme oranını arttırdığını belirtmişlerdir. Eğlence, mobil reklamcılığın önemli faktörlerinden birisidir. Tüketiciler tarafından eğlenceli ve komik olarak algılanan reklam mesajları, ilgi uyandırmakta ve tüketici sadakati yaratmaktadır (Xu, 2007: 11).

Reklam ile etkileşime girildiğinde, reklama karşı duyulan yüksek düzeyde ilgi ve keyfin, tüketicilerin öznel algıları ve ruh halleri üzerinde olumlu bir etkisinin olduğu tespit edilmiştir (Hoffman ve Novak, 1996: 65). Bu nedenle birçok mobil reklamcılık uygulamasında görsel uygulamalar, müzik, oyunlar ve sosyal medya kullanılmaktadır (Nabus ve Hussin, 2015: 4).

Rahatsız etme, mobil reklamcılığa yönelik tüketici tutumlarının olumsuz boyutu olarak kabul edilmektedir. Tüketicilerin reklamları eleştirmelerinin en önemli nedenlerden birisi, müşteri odaklı olmayan reklamların çok sık gelmesinden rahatsız olmalarıdır (Lee ve Hsieh, 2009:1232). Sinirlendirici, rahatsız edici, hakaret edici veya manipüle edici reklamclık teknikleri, tüketicilerin reklamları hoşa gitmeyen ve rahatsız edici olarak algılamalarına neden olmaktadır (Ducoffe, 1996: 23).

Reklamın güvenilirliği, tüketicilerin ihtiyaçlarını karşılayabilecekleri ürünlerin, reklamlarda sunulduğu yönündeki inançlarıdır (Brackett ve Carr, 2001: 29). MacKenzie ve Lutz (1989)'a göre güvenilirlik, "tüketicinin reklamı yapılan markanın öne sürdüğü iddiaları ne derece doğru ve güvenilir olarak algıladığıdır (Nabus ve Hussin, 2015:5). Güvenilirlik, mobil reklamı kabullenmede etkili olmaktadır (Merisavo vd., 2007: 41).

Kişiselleştirme, pazarlamacıların potansiyel müşterilerine bireysel olarak ulaşmalarını sağlayarak tüketici ile olan ilişkilerini güçlendirmektedir (Saadeghvaziri ve Hosseini, 2011:395). Yan vd. (2004), kişiselleştirilmiş bir mobil reklamın, belirli müşterileri hedeflediğini ve mesaj içeriğinin tüketicilerin demografik özelliklerine, tercihlerine, alışkanlıklarına ve alışveriş yapma sıklıklarına göre uyarlandığını belirtmektedirler (Saadeghvaziri ve Hosseini, 2011: 395). Reklamın teşvik etme yönü, belirli bir promosyon ya da kampanya ile ilgili reklam mesajlarını almayı kabul eden tüketicilere belirli finansal ödüllerin verilmesidir. Finansal teşvikler, insanları doğrudan pazarlama programlarına çeken itici bir güç olarak görülmektedir (Nabus ve Hussin, 2015: 5). Mobil reklamcilıkta tüketicilere finansal avantajlar sunarak reklam verenlerin değer yaratacağı düşünülmektedir (Saadeghvaziri ve Hosseini, 2011: 397). Son olarak reklamın etkileşimlilik yönü, tüketici tutumlarını etkileyebilecek faktörlerden birisidir (Raines, 2013: 129). Liu (2003)'nun çalışması etkileşime ilişkin olumlu algıların, olumlu tutumların güçlü belirleyicisi olabileceğini göstermektedir.

Reklama yönelik tutumların belirlenmesi, tutumların reklamı kabullenme üzerinde etkili olabileceğinden dolayı oldukça önemlidir. Yapılan çalışmalar tutumun, tüketicinin reklamlara maruz kalmasını, reklamlara olan dikkatini ve bireysel reklamlara gösterdiği tepkiyi etkilediğini göstermektedir (Schlosser, Shavitt veKanfer, 1999; Cheng vd., 2009). Tutum, "bir kişinin bir obje veya fikre karşı olumlu veya olumsuz değerlendirmeleri, duygusal hisleri ve davranış eğilimi" olarak tanımlanmaktadır (Tsang vd., 2004: 
66). Tutum, başarılı reklam kampanyaları için en önemli faktörlerden biri olarak gösterilmektedir (Hallgrímsson, 2016: 8). Alwitt ve Prabhakar (1992)'a göre tutumun bu kadar önemli olmasının nedeni, reklamlara yönelik tutumlar ve istenen davranış arasındaki güçlü ve olumlu ilişkidir (Hallgrímsson, 2016: 8).

Reklam değeri, reklamın kabullenilmesinde etkili olan temel reklamcılık performansı ölçüm faktörlerinden biridir (Rabiei, Ganji ve Shamsi, 2012: 741). Ducoffe (1995)'e göre reklam değeri, tüketicilere göre reklamın göreli değerinin ya da faydasının öznel bir değerlendirmesini ifade etmektedir. Ayrıca reklamdan algılanan değer, reklamın etkinliğinin bir ölçütüdür. Bu nedenle reklam değeri, reklamı kabullenme niyetinin belirleyicisi olarak kabul edilmektedir.

Reklam mesajı içeriğini oluşturan boyutlar, reklama yönelik tutumu (Hallgrímsson, 2016; Parreno vd., 2013; Raines, 2013), reklamın değerini (Haghirian vd., 2008) ve tüketicilerin reklamı kabullenme durumlarını (Westerlund vd., 2009; Rabiei vd., 2012; Demirgüneş ve Avcılar, 2016) etkilemektedir. Parreno vd. (2013) mobil reklamı kabullenmeyi, tüketicilerin mobil reklamları almak için istekli olmaları; Scharl vd. (2005) ise mobil reklamlardan memnun olmaları şeklinde tanımlamaktadırlar. Ancak, bu durumun aksine tüketiciler, ilgi duymadıkları bir reklamla karşılaştıklarında mobil reklamlardan kaçınma davranışı da gösterebilmektedirler (Rosaj-Mendez, Davies ve Madran, 2009: 947). Tutum ve reklamın algılanan değeri, mobil reklam alma konusunda tüketicilerde istek oluşturabilecek faktörlerdendir. Mobil reklama yönelik olumlu tutumlar, kaçınmayı azaltarak mobil reklama olan ilgiyi artırmaktadır (Parreno vd., 2013: 732). Ayrıca, algılanan reklam değeri düşük olduğunda, tüketiciler reklama ilgi duymamaktadırlar (Nabus ve Hussin, 2015: 1).

\subsection{Uygulama İçi Reklamlar}

Son yıllarda önem kazanmaya başlayan mobil uygulamalar, reklam verenler için mevcut birçok yeni reklam fırsatı arasından en etkili ve dikkat çekici fırsatlardan birisi olarak görülmektedir (Raines, 2013: 126). Valvi ve West (2015:349) mobil uygulamaları, "belirli görevleri yerine getiren ve kullanıcılara değer sağlayan taşınabilir bir aygıt üzerinde çalışan yazılım" olarak tanımlamaktadırlar.

Sosyokültürel ve ekonomik bir fenomen olan ve son on yıldır var olan uygulama ekonomisi, App Store ve Android Apps ile gelişme göstermektedir (Raines, 2013: 126). App Annie (The App Analytics and App Data Industry Standard) tarafından hazırlanan rapora göre; 2017 yılında yaklaşık 197 milyar uygulama indirilmiş ve mobil uygulamalardan elde edilen gelir 127 milyar dolara ulaşmıştır.

Çok sayıdaki uygulama içi mobil reklam türü içerisinde yaygın olan reklam türleri, ekran üzerinde ekran içeriği ile birlikte görüntülenen banner reklamlar, uygulamadaki faaliyetten önce veya sonra öne çıkan geçiş (video) reklamları, tıklayınca-büyüyen reklamlar, interstitial (tam sayfa) reklamlar ve tıkla indir uygulama reklamlarıdır (Bhave vd., 2013: 64). Banner reklamlar, bir hedef reklamla bağlantılı link içeren, uygulama ekranının üst veya alt kısmında yayınlanan, $468 \times 60$ veya $234 \times 60$ piksel boyutunda statik (durağan), animasyonlu (hareketli), interaktif (etkileşimli) olabilen küçük, genelde dikdörtgen şeklinde olan grafik görüntüleridir (Novak ve Hoffman, 1996: 4). Bu reklamlar, düşük maliyetli olduklarından ve kolay bir biçimde oluşturulabildiklerinden dolayı reklam verenler tarafından tercih edilmektedir. Reklam verenler banner reklamlarla, tüketicilerin geçmiş davranışlarına dayalı olarak demografik bilgilerini hedefleyebilmektedirler. Kullanıcıların, uygulama ile kesintisiz olarak etkileşim kurabilmesine imkân vermesi, banner reklamların, diğer reklam türlerine göre daha yaygın kullanılmasının en önemli sebeplerinden birisidir (Fleit, 2014).

Interstitial reklamlar; uygulamanın içeriğini engelleyen görsel, html bir sayfa veya tam sayfa olarak karşılaşılan reklamlardır. Interstitial reklamlar, banner reklamların tersine kullanıcıları reklamı tıklayarak etkileşime geçmeye zorlamaktadır. Bu sayede interstitial reklamlar, kullanıcıların dikkatini çekmekte ve yüksek dönüşüm oranlarını korumaktadır. Etkileşimli video reklamları ise kullanıcılar uygulamaları başlattığında, onlarla etkileşimde bulunmaya başlayan ve kullanıcının 5 saniye sonra atlayabildiği reklamlardır. Video reklamları genellikle uygulamalardaki doğal duraklamalar sırasında oluşmaktadır (Fleit, 2014). Interstitial reklamlar ve etkileşimli geçiş (video) reklamları, genellikle art arta bölümleri olan oyunlarda ve uygulamalarda kullanılmaktadır. Kullanıcı, uygulamadaki aktivitenin bir bölümünü tamamlamakta ve sonrasında başka bir düzeye geçmektedir. Söz konusu reklamlar, kullanıcı bir sonraki düzeye geçmek için beklediği sürede ve kullanıcı reklamlara karşı daha duyarlı olduğunda etkili olmaktadır. Bir diğer form olan 
tıkla indir uygulama reklamları ise, uygulamaları hedefli mobil kullanıılara tanıtmak ve uygulamaların indirilme sayısını artırmak amacıyla uygulama mağazasına bağlantı veren metin veya banner reklamlardır (Yücel, 2017). Tıklayınca büyüyen reklamlar, aynı sayfada marka ile ilgili kapsamlı bilgilerle birlikte boyutu genişleyen reklamlardır. Bu durumda, kullanıcı başka bir sayfaya yönlendirilmediğinden kullanıcı zaman kazanmaktadır (Bhave vd., 2013: 64).

Uygulama içi mobil reklamlar ile ilgili literatür incelendiğinde, tüketicilerin uygulama içi mobil reklamlara yönelik tutumlarını konu alan çalışmaların (Bhave vd., 2013; Hallgrímsson, 2016) az sayıda olduğu görülmektedir. Raines (2013), uygulama içi mobil reklamlara yönelik tüketici tutumlarını, tutum ve davranış kapsamında ele alan araştırmacılardandır. Raines (2013)'a göre tüketicilerin uygulama içi mobil reklamlara yönelik tutumları olumsuz yöndedir. Raines (2013)'ın çalışmasının aksine, mobil kullanıcılar, uygulama içi mobil reklamlara yönelik farklı ve hatta olumlu tutumlara sahip olabilmektedirler. Bu durum, katılımcıların uygulama içi reklamları önemsediğini gösteren Bhave vd. (2013)'nin yaptığı bir çalışma ile tespit edilmiştir. Söz konusu çalışmada, eğlendirme ve bilgilendirme boyutlarının, uygulama içi reklamlara yönelik tutumların en güçlü belirleyicileri olduğu; banner ve video reklamlarının, bilgilendirici olmadığı takdirde rahatsız edici olarak düşünüldüğü sonucuna ulaşmışlardır. Ayrıca araştırmacılar, uygulama içi reklamlara yönelik tutumlar hakkında daha fazla bilgi elde edinmek için nicel bir araştırmaya ihtiyaç olduğunu belirtmişlerdir. Hallgrímsson (2016)'un çalışmasında ise, akıllı telefon kullanıcılarının tutumları ile reklamları fark etme, okuma ve tıklama niyeti arasında güçlü ve olumlu bir ilişki olduğunu ortaya koymuştur. Bhave vd. (2013)'nin çalışmasına benzer olarak uygulama içi mobil reklamlardan algılanan eğlence boyutunun, reklamlara yönelik tutumlar üzerinde güçlü ve olumlu bir etkiye sahip olduğu, güvenilirlik ve bilgilendirme boyutlarının ise orta derecede bir etkiye sahip olduğu tespit edilmiştir. Diğer taraftan rahatsız etme boyutunun, tutumları olumsuz yönde etkilediği; kişiselleştirme boyutunun ise tutumlar üzerinde belirgin bir etkiye sahip olmadığı sonucuna ulaşılmıştır (Hallgrímsson, 2016: 4).

\section{Araştırmanın Modeli ve Hipotezleri}

Araştırmada akıllı telefonlarda yer alan uygulamalara gelen mobil reklamların bilgilendirme, eğlendirme, kişiselleştirme, rahatsı etme, teşvik etme, güvenilirlik ve etkileşimlilik özelliklerinin; reklama yönelik tutum, reklamın algılanan değeri ve reklamı kabullenme üzerindeki etkileri değerlendirilmektedir. Buna göre mobil reklam mesajlarının içerik özellikleri, tutum, reklam değeri ve tüketicilerin mobil reklamı kabullenmeleri arasındaki ilişkiler ortaya konulmaktadır. Söz konusu ilişkileri yansıtan araştırma modelinin geliştirilmesinde Raines (2013), Kim ve Han (2014), Demirgüneş ve Avcılar (2016) tarafından yapılan çalışmalardan yararlanılmıştır. Araştırmanın modeli Şekil 1'de sunulmaktadır. Belirtilen çalışmalardan farkı olarak, bu çalışmada araştırmanın modeli üç ayrı mobil reklam türü (banner reklam, interstitial reklam, etkileşimli geçiş reklamı) açısından değerlendirilmektedir. Araştırma modelinde belirtilen ve hipotezlerde sunulan ilişkiler, her bir mobil reklam türüne yönelik üç ayrı regresyon denklemi kurularak test edilmiştir.

Araştırma modeli kapsamında test edilecek hipotezler şu şekildedir:

$\boldsymbol{H}_{\mathbf{1}}$ : Mobil reklamın bilgilendirme boyutu, mobil reklama yönelik tutumu istatistiksel olarak anlamlı bir şekilde etkilemektedir.

$\boldsymbol{H}_{2}$ : Mobil reklamın eğlendirme boyutu, mobil reklama yönelik tutumu istatistiksel olarak anlamlı bir şekilde etkilemektedir.

$\boldsymbol{H}_{3}$ : Mobil reklamın rahatsız etme boyutu, mobil reklama yönelik tutumu istatistiksel olarak anlamlı bir şekilde etkilemektedir.

$\boldsymbol{H}_{4}$ : Mobil reklamın güvenilirlik boyutu, mobil reklama yönelik tutumu istatistiksel olarak anlamlı bir şekilde etkilemektedir.

$\boldsymbol{H}_{5}$ : Mobil reklamın teşvik etme boyutu, mobil reklama yönelik tutumu istatistiksel olarak anlamlı bir şekilde etkilemektedir.

$\boldsymbol{H}_{\mathbf{6}}$ : Mobil reklamın kişiselleştirme boyutu, mobil reklama yönelik tutumu istatistiksel olarak anlamlı bir şekilde etkilemektedir. 
$\boldsymbol{H}_{7}$ : Mobil reklamın etkileşimlilik boyutu, mobil reklama yönelik tutumu istatistiksel olarak anlamlı bir şekilde etkilemektedir.

$\boldsymbol{H}_{\mathbf{8}}$ : Mobil reklama yönelik tutum, mobil reklamın algılanan değerini istatistiksel olarak anlamlı bir şekilde etkilemektedir.

$\boldsymbol{H}_{9}$ : Mobil reklamdan algılanan değer, mobil reklamı kabullenmeyi istatistiksel olarak anlamlı bir şekilde etkilemektedir.

Şekil 1. Araştırmanın Kavramsal Modeli

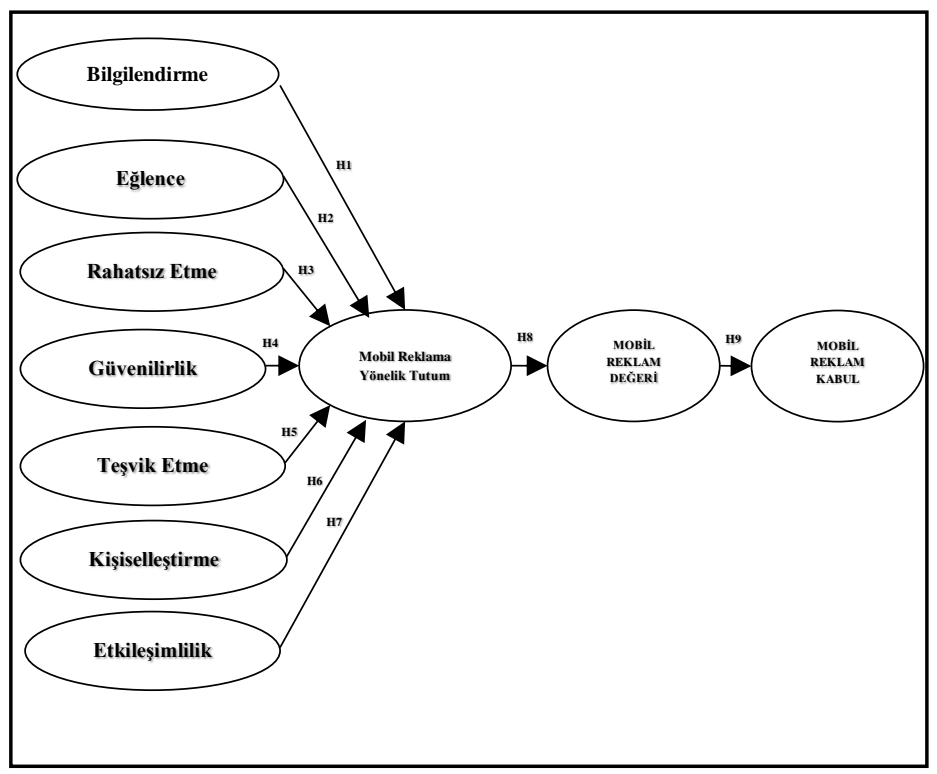

\section{Araştırmanın Yöntemi}

\subsection{Araştırmanın Ana Kütlesi ve Örnekleme Süreci}

Bu çalışma, 5,271 milyon nüfusa sahip olan Ankara'da ikamet eden 18-65 yaş arası akıllı telefon kullanıcılarını kapsamaktadır. Ana kütle büyüklüğü dikkate alındığında zaman ve maliyet kısıtları çerçevesinde, çalışma için gerekli olan veriler, 01.06.2017-30.06.2017 tarihleri arasında Ankara'da yaşayan 550 akıllı telefon kullanıcısından kolayda örnekleme tekniği kullanılarak, yüz yüze anket yöntemi ile elde edilmiştir.

\subsection{Veri Toplama Yöntemi ve Aracı}

Araştırmada veri toplama yöntemi olarak anket formu kullanılmıştır. Anket formu üç bölümden oluşmaktadır. Birinci bölümde katılımcıların demografik özellikleri, akılı telefonlarda yer alan uygulamalara gelen mobil reklam türlerini alma sıklıkları, mobil reklamları takip etme durumları ve akıllı telefonlarda yer alan uygulamaları kullanım durumlarıyla ilgili bilgiler yer almaktadır. İkinci bölümde mobil reklamların içerik özellikleri ile ilgili değişkenlere; üçüncü bölümde ise reklama yönelik tutum, reklamın değeri ve mobil reklamı kabullenme değişkenlerini ölçen ifadelere yer verilmektedir. Belirtilen değişkenler 5 'li Likert ölçeği kullanılarak ölçülmüştür. Ölçümde kullanılan bilgilendirme boyutu Tsang vd. (2004), Raines (2013), Kim ve Han (2014), Hallgrímsson (2016); eğlence boyutu Tsang vd. (2004), Raines (2013), Hallgrímsson (2016); rahatsız etme boyutu Tsang vd. (2004), Raines (2013), Hallgrímsson (2016); güvenilirlik boyutu Tsang vd. (2004), Raines (2013), Hallgrímsson (2016); teşvik etme boyutu Tsang vd. (2004), Demirgüneş ve Avcılar (2016); kişiselleştirme boyutu, Saadeghaviziri ve Hosseini (2011), Hallgrímsson (2016); etkileşimlilik boyutu Raines (2013); tutum ve mobil reklam değeri boyutu Raines (2013), Hallgrímsson (2016) ve mobil reklamı 
kabullenme boyutu Merisavo vd. (2007), Demirgüneş ve Avcılar (2016) ile Hallgrímsson (2016)'ın çalışmalarında yer alan ölçekler kullanılarak ölçülmüştür.

\subsection{Verilerin Analiz Yöntemi}

Tüketicilerin mobil reklamı kabullenmeleri üzerinde etkisi olan faktörleri (bilgilendirme, eğlence, rahatsız etme, güvenilirlik, teşvik etme, kişiselleştirme, etkileşimlilik, tutum ve mobil reklam değeri) oluşturan değişkenlerin içsel tutarlılığı, Cronbach's alfa katsayıları hesaplanarak tespit edilmiştir. Ölçüm modelinde yer alan kavramsal yapıları belirlemek için keşifsel faktör analizi (exploratory factor analysis) gerçekleştirilmiştir. Keşifsel faktör analizi, bir grup değişken arasında ilişkilere dayanarak verilerin daha anlamlı ve özet bir biçimde sunulmasını sağlayan, tüm değişkenler arasındaki karşılıkı ilişkilerle ilgilenen çok değişkenli bir analiz türüdür (Nakip, 2013: 511). Keşifsel faktör analizinin en önemli amacı, değişkenler arasındaki karşılıklı bağımlılı̆ın kökenini araştırmaktır (Kurtuluş 2010:189). Söz konusu analiz, çok sayıda değişken arasındaki doğrusal ilişkilere dayanarak verilerin $f$ aktörler tarafından daha anlamlı ve özet bir biçimde açıklanmasını sağlayan bir analiz yöntemidir (Nakip, 2013:511).

Araştırma modelinde yer alan değişkenlerin, tüketicilerin akıllı telefonlarda yer alan uygulamalara gelen mobil reklamları kabulüne olan etkilerini tespit etmek ve araştırma hipotezlerini test etmek için hiyerarşik regresyon analizi yapılmıştır. Regresyon analizi, bir bağımlı (kriter) değişken ile bir veya daha fazla sayıda bağımsız (tahmin edici) değişken arasındaki doğrusal ilişkileri tespit eden analiz yöntemidir (Hair vd., 1998:17). Hiyerarşik regresyon analizi, çoklu regresyon analizinin bir türü olmakla birlikte, araştırma sürecinde hangi değişkenlerin hangi sırayla analize dahil edileceğine araştırmacının karar verdiği bir analiz yöntemidir. Söz konusu yöntem, modelde yer alan diğer değişkenlerin etki düzeyini dikkate almakta; modele eklenen her bir yeni değişkenin, bağımlı değişkendeki varyans açıklama düzeyi ile ilgilenmektedir (Tabachnick ve Fidell, 2013:137). Hiyerarşik regresyon analizinde üç aşama bulunmaktadır. Illk aşamada, bağımlı değişken, mobil reklama yönelik tutum; bağımsız değişkenler ise bilgilendirme, eğlence, rahatsız etme, güvenilirlik, teşvik etme, kişiselleştirme ve etkileşimliliktir. İkinci aşamada, bağımlı değişken algılanan mobil reklam değeridir. Bağımsız değişkenlere ilave olarak mobil reklama yönelik tutum değişkeni eklenmiştir. Üçüncü aşamada ise bağımlı değişken mobil reklam kabulüdür. Bu aşamada bağımsız değişkenlere ilave olarak mobil reklam değeri değişkeni eklenmiştir. Araştırma verileri, IBM SPSS 24.0 istatistik paket programı ile analiz edilmiştir.

\section{Analiz Sonuçları ve Bulgular}

\subsection{Cevaplayıcıların Demografik Özellikleri ve Tanımlayıcı İstatistikleri}

Ankete cevap veren 550 akıllı telefon kullanıcısının demografik özellikleri ile mobil reklam davranışlarına ilişkin tanımlayıcı istatistik bilgileri Tablo 1'de sunulmaktadır. Ankete cevap veren katılımcıların \%52'si erkek, \%48'i kadınlardan oluşmaktadır. Kullanıcıların \%39'u 26-35 yaş aralığında, \%59'u evli, \%64'ü lisans mezunu ve \%67'si memur olduklarını belirtmişlerdir. Araştırmaya katılan kullanıcıların \%59'u ortalama aylık gelirlerinin 3.001-4.600 TL düzeyinde olduğunu belirtmişlerdir. Kullanıcıların \%29'u akıllı telefonlarında yer alan uygulamalara en sık gelen mobil reklam türünün banner reklam olduğunu belirtirken, yine \%29'u akıllı telefonlarında yer alan uygulamalara gelen mobil reklam türü olarak banner reklamları tercih ettiklerini belirtmişlerdir. Kullanıcıların büyük çoğunluğu, her 5 tür reklam için akıllı telefonlarında yer alan uygulamalara günde ortalama gelen mobil reklam sayısının, 1 ile 3 adet arasında olduğunu ifade etmiştir. Araştırmaya katılan kullanııların \%49'u akıllı telefonlarında yer alan uygulamalara gelen mobil reklam mesajlarını vakit bulunca okuduklarını belirtirken; hemen okuyanların oranı \%4, mesajın kaynağına bağlı olarak okuyanların oranı \% 25 ve mesajın içeriğine bağlı olarak okuyanların oranı ise \%22olarak belirlenmiştir. Araştırmaya katılan kullanıcıların \%34'ü mobil reklamları çoğunlukla giyim mağazalarından aldıklarını belirtirken, \%22'si mobil reklamları bankalardan aldıklarını, \%17'si ise mobil oyunlardan aldıklarını belirtmişlerdir. Son olarak kullanııların \%20'si akıllı telefonlarında yer alan uygulamalar içerisinde sosyal ağ sitelerini (Facebook, Twitter, Instagram, WhatsApp vb), \%9'u içerik ve Medya uygulamalarını (YouTube, Spotify, Kindle, Haber uygulaması vb.) ve Alışveriş Uygulamalarını (Trendyol, Morhipo, Markafoni, Migros, Aktüel Ürünler, Ali 
Express Shopping App, N11.com, Hepsiburada vb.) çok sık kullandıklarını belirtirlerken, \%6'sı yaşam tarzı, sağlık ve diğer uygulamaları (Runtastic, NikePlus vb.) hiç kullanmadıklarını belirtmişlerdir (bkz. Ek 1).

\subsection{Keşifsel Faktör Analizi Sonuçları}

Tüketicilerin akıllı telefonlarda yer alan uygulamalara gelen mobil reklamlara yönelik tutumları üzerinde etkili olan boyutları tespit etmek için gerçekleştirilen keşifsel faktör analizinde, değişkenleri faktörleştirme yöntemi olarak temel bileşenler yöntemi ve varimax rotasyon yönteminden yararlanılmıştır. Ayrıca faktör sayısını belirlemede öz değeri 1'den büyük olan faktörler dikkate alınmıştır. Faktör analizinde kullanılan veri setinin analize uygunluğunu tespit etmek için KMO testi ve Barlett's Sphericity testinden yararlanılmıştır. KMO testi, örnekleme yeterliliğini ölçmeye yarayan bir test olup, örnek büyüklüğü ile ilgilenmektedir. Faktör analizinin uygulanabilmesi için KMO test sonucunun, \%60'dan yüksek olması istenmektedir (Nakip, 2013:518). Bu çalışmada veri setinin KMO değeri (bkz. Tablo 3) \%94,7 düzeyinde hesaplanmıştır. Hesaplanan değer, veri setinin faktör analizine uygun olduğunu ifade etmektedir. Bunun yanında Barlett's Sphericity testi, faktör analizi için kullanılacak korelasyon matrisinin, birim matris olup olmadığını test etmektedir. Testin anlamlılık düzeyinin 0.05 'den küçük olması, korelasyon matrisinin birim matris olmadığını ve böylece veri setinin faktör analizine uygun olduğunu göstermektedir. Bu çalışmada kullanılan veri seti için Barlett's testinin anlamlılık düzeyi 0.05'den küçük olarak hesaplanmıştır (bkz. Ek 2). Buna göre veri setinin, faktör analizine uygun olduğuna karar verilmiştir. Keşifsel faktör analizi sonuçları Ek 2 'de yer almaktadır.

Ek 2'de yer alan veriler incelendiğinde, ilk yapılan keşifsel faktör analizi sonucunda güvenilirlik boyutu altında" akıllı telefonumda yer alan uygulamalara gelen mobil reklamların güvenilir olduğunu düşünürsem o reklamı tıklarım", "akıllı telefonumda yer alan uygulamalar içerisinde reklam veren markaların güvenilir olduğunu düşünmüyorum", "akıllı telefonumda yer alan uygulamalar içerisinde reklamı yapılan bir markaya güvenmek için markanın reklamını en az başka bir medyada daha görmem gerekir"; teşvik etme boyutu altında "bana teşvik verildiği halde verilerimi tanınmamış bir markayla paylaşmak istemem"; kişiselleştirme boyutu altında" akıllı telefonumda yer alan uygulamalara gelen mobil reklamların konusunu kendim belirlemek isterim", "akıllı telefonumda yer alan bir uygulamada reklam veren bir marka reklamını benim için özelleştirirse o reklamı beğenirim", "kişiselleştirilmiş bir uygulamaya gelen mobil reklam daha fazla ilgimi çeker" değişkenleri, faktör yüklerinin düşük olması ve farklı faktörler altında yüksek çapraz faktör yükü olması nedeniyle analiz dışı bırakılmıştır.

Keşifsel faktör analizi sonucunda tüketicilerin akıllı telefonlarda yer alan uygulamalara gelen mobil reklam mesajlarının içerik özelliklerine ilişkin yedi faktör tespit edilmiştir. Bu faktörler; bilgilendirme, eğlence, rahatsız etme, güvenilirlik, teşvik etme, kişiselleştirme ve etkileşimlilik olarak belirlenmiştir. Öz değeri 1'denbüyük söz konusu yedi faktör, toplam varyansın \%78,52'sini açıklamaktadır. Bilgilendirme boyutu en yüksek $(\% 14,69)$ düzeyde varyans açıklayarak birinci sırada faktörleşmiştir. Etkileşimlilik boyutu ise görece düşük $(\% 9,18)$ düzeyde açıklanan varyans düzeyi ile son sırada faktörleşmiştir. Mobil reklam mesajlarının içerik özelliklerine ilişkin yedi boyut içerisinde bilgilendirme boyutunun, en önemli boyut olduğunu söylemek mümkündür.

\subsection{Güvenilirlik Analizi Sonuçları}

Güvenilirlik, ölçmelerin tekrarlanması halinde ortaya çıkan tutarlı sonuçlardır. Bir araştırmanın tekrarlanması durumunda aynı sonuçların elde edilip edilemeyeceğini, cevaplayıcıların durumlarında bir değişiklik olmadığı sürece aynı cevapları verip vermeyeceklerinin göstergesidir (Nakip, 2013: 203). Kullanılan ölçeğin güvenilirlik düzeyi (ölçeğin içsel tutarlılı̆ı)), ölçeği oluşturan değişkenlere ilişkin Cronbach's Alfa katsayısı hesaplanarak tespit edilebilmektedir. Herhangi bir ölçeğin güvenilirliğinden söz edebilmek için hesaplanan Cronbach's Alfa katsayısının \%70'den yüksek olması beklenmektedir. Ölçüm modelinde yer alan, her bir boyutu ölçmede kullanılan gözlenen değişkenlere ilişkin Cronbach's Alfa değerleri, Tablo 2'de sunulmaktadır. Her bir boyut için hesaplanan Cronbach's Alfa katsayıları; eğlence boyutunda \%95, rahatsız etme boyutunda \%94, bilgilendirme boyutunda \%93, güvenilirlik boyutunda \%93, kişiselleştirme boyutunda $\% 90$, etkileşimlilik boyutunda \%94, teşvik etme boyutunda \%93, tutum boyutunda \%95, banner reklam için 
mobil reklam değeri boyutunda \%94, interstitial (tam sayfa) reklam için mobil reklam değeri boyutunda \%95, etkileşimli geçiş (video) reklam için mobil reklam değeri boyutunda \%95, banner reklam için mobil reklam kabulü boyutunda \%95, interstitial (tam sayfa) reklam için mobil reklam kabulü boyutunda \%95 ve etkileşimli geçiş (video) reklam için mobil reklam kabulü boyutunda \%95 olarak hesaplanmıştır. Güvenilirlik analizi sonucunda ölçüm aracının güvenilirliğinin, önerilen \%70 değerinden yüksek olduğu ve böylece ölçüm aracının güvenilir olduğu tespit edilmiştir.

\subsection{Hiyerarşik Regresyon Analizi Sonuçları}

Araştırma modelinde yer alan değişkenlerin, tüketicilerin akıllı telefonlarda yer alan uygulamalara gelen mobil reklamları kabulüne olan etkilerini tespit etmek için her bir mobil reklam türüne yönelik üç ayrı regresyon denklemi kurulmuş ve her bir tür için ayrı ayrı hiyerarşik regresyon analizi yapılmıştır.

Hiyerarşik regresyon analizi sonuçları sırasıyla; Ek 3 (Banner), Ek 4 (Interstitial, Tam Sayfa) ve Ek 5'de (Etkileşimli Geçiş, Video) sunulmuştur. Belirtilen tablolarda ilgili reklam türü için bağımlı ve bağımsız değişkenlere ait beta katsayıları, katsayılara ait $t$-istatistik değerleri, $R^{2}$ değerleri, $R^{2}$ deki değişim değerleri, $F$ değerleri, $\mathrm{F}^{\prime}$ deki değişim değerleri, $\mathrm{sr}^{2}$ (yarı kısmi korelasyon değerleri) ve anlamlılık düzeyleri yer almaktadır.

\subsubsection{Banner Reklam İçin Hiyerarşik Regresyon Analizi Sonuçları}

Banner, interstitial ve etkileşimli geçiş (video) reklamlar için, ilk kurulan modelin bağımlı değişkeni (tutum); bağımsız değişkenleri ise, bilgilendirme, eğlence, rahatsız etme, güvenilirlik, teşvik etme, kişiselleştirme ve etkileşimliliktir. ikinci kurulan modelin bağımlı değişkeni (mobil reklam değeri)'dir. Bağımsız değişken olarak ise diğer bağımsız değişkenlere ilave olarak mobil reklama yönelik tutum değişkeni eklenmiştir. Üçüncü kurulan modelin bağımlı değişkeni (mobil reklam kabulü); bağımsız değişkenleri ise diğer bağımsız değişkenlere ilave olarak mobil reklam değeridir.

Ek 3'de yer alan keşifsel faktör analizi sonuçlarına göre; Banner reklamlar için etkileşimlilik ( $\beta=0.252$, $p<0.01)$, eğlence $(\beta=0.181, p<0.01)$, güvenilirlik $(\beta=0.144, p<0.01)$ rahatsız etme $(\beta=-0.114, p<0.01)$ ve bilgilendirme $(\beta=0.067, p<0.05)$ boyutlarının, mobil reklama yönelik tutum düzeyini istatistiksel olarak anlamlı bir şeklide etkilediği tespit edilmiştir. Ancak, teşvik etme ve kişiselleştirme boyutlarının, mobil reklama yönelik tutum düzeyini istatistiki olarak anlamlı bir şekilde etkilemediği $(p>0,05)$ belirlenmiştir. Banner reklamlara yönelik tutumun, banner reklamlardan algılanan mobil reklam değeri üzerinde pozitif ve istatistiki olarak anlamlı bir etkiye sahip olduğu tespit edilmiştir $(\beta=0.554, p<0.01)$. Son olarak, banner reklamlardan algılanan mobil reklam değerinin, banner reklamların kabulü üzerinde pozitif ve istatistiki olarak anlamlı bir etkiye sahip olduğu belirlenmiştir $(\beta=0.483, p<0.01)$.

Banner reklamlar için; hiyerarşik çoklu regresyon analizinin birinci aşamasında, bilgilendirme, eğlence, rahatsız etme, güvenilirlik, teşvik etme, kişiselleştirme ve etkileşimlilik boyutları, regresyon modeline anlamlı katkıda bulunmuşlar ( $F=49,839, p<.001)$; ve söz konusu değişkenler, tutumdaki değişimin \%39,2'sini açıklamışlardır. Analizin ikinci aşamasında, mobil reklama yönelik tutum modele eklendiğinde; reklama yönelik tutum değişkeni, algılanan mobil reklam değerindeki değişimin $\% 11,2^{\prime}$ sini açıklamıştır. $\mathrm{R}^{2}$ deki bu değişim anlamlı bulunmuştur ( $F=68,621, p<.001)$. Analizin üçüncü aşamasında, algılanan mobil reklam değeri boyutu model eklenmiş ve söz konusu boyut, mobil reklam kabulündeki değişimin \%9,3'ünü açıklamıştır. $\mathrm{R}^{2 \prime}$ deki bu değişim anlamlı bulunmuştur $(\mathrm{F}=88,785, \mathrm{p}<.001)$.

Hiyerarşik regresyon analizinin birinci aşaması için kısmi korelasyon katsayısını ifade eden ${s r^{2}}^{2}$ değerlerine bakıldı̆̆ında, mobil reklama yönelik tutum üzerinde açıklanan varyans değerleri en yüksek dört faktörün; etkileşimlilik $\left(s r^{2}=\% 2\right)$, eğlence $\left(s r^{2}=\% 2\right)$, güvenilirlik $\left(s r^{2}=\% 1\right)$ ve rahatsız etme $\left(s r^{2}=\% 1\right)$ faktörleri olduğu; etkileşimlilik, eğlence ve güvenilirlik faktörlerinin tutumu pozitif yönde etkilediği, rahatsız etme faktörünün ise tutumu negatif yönde etkilediği görülmektedir. İkinci aşamada, diğer faktörlere kıyasla mobil reklam değeri üzerinde açıklanan varyans değeri en yüksek olan faktörün, tutum $\left(s r^{2}=\% 11\right)$ olduğu görülmektedir. Mobil reklama yönelik tutum, mobil reklam değerini pozitif yönde etkilemektedir. Üçüncü aşamada ise, diğer faktörlere kıyasla mobil reklam kabulü üzerinde açıklanan varyans değeri en yüksek faktör, mobil reklam değeri $\left(s r^{2}=\% 9\right)$ olmaktadır. 


\subsubsection{Interstitial (Tam Sayfa) Reklam İçin Hiyerarşik Regresyon Analizi Sonuçları}

Ek 4'te yer alan hiyerarşik regresyon analizi sonuçlarına göre Interstitial (tam sayfa) reklamlar için; güvenilirlik $(\beta=0.199, p<0.01)$, eğlence $(\beta=0.177, p<0.01)$, etkileşimlilik $(\beta=0.155, p<0.01)$, rahatsı etme $(\beta=-$ $0.151, p<0.01)$, teşvik etme $(\beta=0.086, p<0.10)$ ve bilgilendirme $(\beta=0.044, p<0.05)$ boyutlarının, mobil reklama yönelik tutum düzeyini istatistiksel olarak anlamlı bir şekilde etkilediği tespit edilmiştir. Ancak kişiselleştirme boyutunun, mobil reklama yönelik tutum düzeyi üzerinde istatistiki olarak anlamlı bir etkisinin olmadığı $(p>0,05)$ tespit edilmiştir. Interstitial reklamlara yönelik tutumun ise interstitial reklamlardan algılanan mobil reklam değeri üzerinde pozitif ve istatistiki olarak anlamlı $(\beta=0,458, p<0.01)$ bir etkiye sahip olduğu; son olarak interstitial reklamlardan algılanan mobil reklam değerinin, interstitial reklamların kabulünü pozitif yönde ve istatistiki olarak anlamlı $(\beta=0,647 p<0.01)$ bir şekilde etkilediği belirlenmiştir.

Interstitial (tam sayfa) reklamlar için; hiyerarşik çoklu regresyon analizinin birinci aşamasında, güvenilirlik, eğlence, etkileşimlilik, rahatsız etme, teşvik etme ve bilgilendirme boyutları, regresyon modeline anlamlı katkıda bulunmuştur ( $F=53,797, p<.001)$. Ayrıca, söz konusu değişkenlerin mobil reklama yönelik tutumdaki değişimin \%41'ini açıkladıkları görülmektedir. Analizin ikinci aşamasında, mobil reklama yönelik tutum modele eklendiğinde; reklama yönelik tutum değişkeni, algılanan mobil reklam değerindeki değişimin $\% 8^{\prime}$ ini açıklamıştır. $\mathrm{R}^{2}$ deki bu değişim anlamlıdır $(F=64,105, \mathrm{p}<.001)$.

Analizin üçüncü aşamasında, algılanan mobil reklam değeri boyutu model eklenmiş ve algılanan mobil reklam değeri boyutu, mobil reklam kabulündeki değişimin $\% 20$ 'sini açıklamıştır. ${ }^{2}{ }^{\prime}$ deki bu değişim anlamlı bulunmuştur ( $F=128,937, p<.001)$.

Hiyerarşik regresyon analizinin birinci aşaması için kısmi korelasyon katsayısını ifade eden $s r^{2}$ değerleri, mobil reklama yönelik tutum üzerinde açıklanan varyans değerleri en yüksek üç faktörün; eğlence $\left(s r^{2}=\% 2\right)$, güvenilirlik $\left(s r^{2}=\% 2\right)$ ve rahatsız etme $\left(s r^{2}=\% 2\right)$ faktörleri olduğunu göstermektedir. Eğlence ve güvenilirlik faktörlerinin mobil reklama yönelik tutumu pozitif yönde etkilediği, rahatsız etme faktörünün ise tutumu negatif yönde etkilediği görülmektedir. İkinci aşamada, diğer faktörlere kıyasla mobil reklam değeri üzerinde açıklanan varyans değeri en yüksek olan faktörün mobil reklama yönelik tutum $\left(s r^{2}=88\right)$ olduğu görülmektedir. Tutum, mobil reklam değerini pozitif yönde etkilemektedir. Üçüncü aşamada, mobil reklam kabulü üzerinde açıklanan varyans değeri en yüksek olan faktörün, mobil reklam değeri $\left(s^{2}{ }^{2} \% 20\right)$ olduğu görülmektedir.

\subsubsection{Etkileşimi Geçiş (Video) Reklam İçin Hiyerarşik Regresyon Analizi Sonuçları}

Ek 5 'te yer alan hiyerarşik regresyon analizi sonuçlarına göre etkileşimli geçiş (video) reklamlar için; eğlence $(\beta=0.231, p<0.01)$, güvenilirlik $(\beta=0.205, p<0.01)$, etkileşimlilik $(\beta=0.148, p<0.01)$, rahatsız etme $(\beta=-$ $0.142, p<0.01)$, teşvik etme $(\beta=0.108, p<0.05)$, kişiselleştirme $(\beta=0.085, p<0.05)$ ve bilgilendirme $(\beta=0.072$, $p<0.05)$ boyutlarının, mobil reklama yönelik tutum düzeyini istatistiksel olarak anlamlı bir şekilde etkilediği tespit edilmiştir. Etkileşimli geçiş (video) reklama yönelik tutumun ise etkileşimli geçiş (video) reklamından algılanan mobil reklam değeri üzerinde pozitif ve istatistiki olarak anlamlı $(\beta=0,479, p<0.01)$ bir etkiye sahip olduğu tespit edilmiştir. Son olarak, etkileşimli geçiş (video) reklamlardan algılanan mobil reklam değerinin, söz konusu reklamların kabulü üzerinde pozitif ve istatistiki olarak anlamlı $(\beta=0,663, p<0.01)$ bir etkiye sahip olduğu belirlenmiştir.

Etkileşimli geçiş reklamlar için; hiyerarşik çoklu regresyon analizinin birinci aşamasında, eğlence, güvenilirlik, etkileşimlilik, rahatsız etme, teşvik etme, kişiselleştirme ve bilgilendirme boyutları, regresyon modeline anlamlı katkıda bulunmuşlardır ( $F=59,938, p<.001)$. Belirtilen değişkenler, mobil reklama yönelik tutumdaki değişimin \%44'ünü açıklamışlardır. Analizin ikinci aşamasında, mobil reklama yönelik tutum modele eklendiğinde; reklama yönelik tutum değişkeni, algılanan mobil reklam değerindeki değişimin $\% 8,4^{\prime}$ ünü açıklamıştır. $R^{2 \prime}$ deki bu değişim anlamlı bulunmuştur $(F=73,344, p<.001)$. Analizin üçüncü aşamasında, algılanan mobil reklam değeri boyutu modele eklenmiş ve bu boyut, mobil reklam kabulündeki değişimin \%21'ini açıklamıştır. $R^{2 \prime}$ deki bu değişim anlamlı bulunmuştur ( $\left.F=159,889, p<.001\right)$. 
Hiyerarşik regresyon analizinin birinci aşaması için kısmi korelasyon katsayısını ifade eden $\mathrm{sr}^{2}$ değerlerine bakıldığında, mobil reklama yönelik tutum üzerinde açıklanan varyans değerleri en yüksek üç faktörün; eğlence $\left(s r^{2}=\% 2\right)$, güvenilirlik $\left(s r^{2}=\% 2\right)$ ve rahatsı etme $\left(s r^{2}=\% 2\right)$ faktörleri olduğu; eğlence ve güvenilirlik faktörlerinin mobil reklama yönelik tutumu pozitif yönde etkilediği, rahatsız etme faktörünün ise tutumu negatif yönde etkilediği görülmektedir. İkinci aşamada, diğer faktörlere kıyasla mobil reklam değeri üzerinde açıklanan varyans değeri en yüksek olan faktörün, mobil reklama yönelik tutum $\left(s r^{2}{ }_{=} \% 8\right)$ olduğu belirlenmiştir. Tutum, mobil reklam değerini pozitif yönde etkilemektedir. Üçüncü aşamada, diğer faktörlere kıyasla mobil reklam kabulü üzerinde açıklanan varyans değeri en yüksek olan faktörün mobil reklam değeri $\left(s r^{2}=\% 21\right)$ olduğu görülmektedir.

\section{Sonuç ve Öneriler}

Bu çalışmada akıllı telefonlarda yer alan uygulamalara gelen mobil reklam türlerinin, reklama yönelik tutum ve reklam kabulü üzerindeki etkileri tespit edilmeye çalışılmıştır. Araştırma sonucunda, üç reklam türü için mobil reklama yönelik tutumun ve algılanan değerin mobil reklamı kabullenme üzerinde etkili oldukları tespit edilmiştir. Mobil reklama yönelik tutum aynı zamanda algılanan mobil reklam değeri üzerinde de etkili olmaktadır. Mobil reklama yönelik olumlu tutumlar, reklamın algılanan değerini yükselterek, tüketicilerde mobil reklam alma konusunda istek oluşturabilmektedir. Bu sonuç, Parreno vd. (2013) ile Nabus ve Hussin (2015) tarafından yapılan çalışmaları da destekler niteliktedir.

Mobil reklamın içerik özellikleri, mobil reklama yönelik tutumu ve mobil reklamdan algılanan değeri farklı düzeylerde etkilemektedir. Akıllı telefonlarda yer alan uygulamalara gelen banner reklamlara yönelik tutum üzerinde en etkili faktör etkileşimlilik olmaktadır. Bu bulgu, Raines (2013)'ın etkileşimliliğin, tutumun belirleyicisi olduğu yönündeki sonucunu desteklemektedir. Etkileşimlilik dışında tutum üzerinde en fazla etkiye sahip olan diğer özellikler; eğlence, reklam mesajının güvenilirliği ve bilgilendirmedir. Buna göre banner reklamlara yönelik tutumun olumlu olabilmesi için banner reklam mesajının eğlenceli, güvenilir ve bilgi verici olması gerekmektedir. Tüketici reklam mesajını doğru ve inandırıcı olarak algıladığında, banner reklam mesajına yönelik tutumu da olumlu olmaktadır. Benzer şekilde Raines (2013); eğlence ve güvenilirlik faktörlerinin, uygulama içi mobil reklama yönelik tutum oluşumunda etkili olduğu sonucuna ulaşmıştır. Bunun yanında rahatsızlık veren bir reklam mesajı, tüketicinin reklama yönelik tutumunu olumsuz yönde etkilemektedir. Benzer şekilde, Ducoffe vd. (1996) rahatsız edici mesajların olumsuz olarak algılandığını belirtmişlerdir. Bhave vd. (2013), çalışmalarında eğlendirme ve bilgilendirme boyutlarının, uygulama içi reklamlara yönelik tutumların en güçlü belirleyicileri olduğu ve banner reklamların bilgilendirici olmadığı takdirde rahatsız edici olarak düşünüldüğü sonucuna ulaşmışlardır. Akıllı telefonlarda yer alan uygulamalara gelen banner reklamlara yönelik tutumun olumlu olabilmesi için öncelikle mesajın etkileşimli olması, eğlenceli, inandırıcı ve bilgi verici olması gerekmektedir. Bununla birlikte mesajın kişiselleştirilmiş ve teşvik edici olmasının reklama yönelik tutum üzerinde istatistiksel olarak anlamlı bir etkisi bulunmamaktadır. Bu durum Xu, (2006) ile Saadeghaviziri ve Hosseini (2011) tarafından yapılan çalışmalardan farklılık göstermektedir.

Banner reklam için içerik özelliklerinin algılanan değer üzerindeki etkileri değerlendirildiğinde; tüketici açısından banner reklamı en çok değerli kılan özellikler eğlence ve bilgilendirmedir. Bu bulgu, Westerlund vd. (2009)'nin bilginin değerin tahmincisi olduğu yönündeki sonucunu desteklemektedir. McQuail'e göre "eğlence, tüketicilerin gerçeklerden kaçma ve keyif duyma isteklerini karşıladığı ve duygusal açıdan tüketicileri rahatlatabildiği için değerlidir (Lee ve Hsieh, 2009:1232). Reklam ile etkileşime girildiğinde, reklama karşı duyulan yüksek düzeyde ilgi ve keyfin, tüketicilerin öznel algıları ve ruh halleri üzerinde olumlu bir etkisinin olduğu tespit edilmiştir (Novak ve Hoffman, 2000:4). Reklam veren, eğlendirici özellikler ekleyerek mesajın algılanan değerini artırabilecektir.

Akıllı telefonlarda yer alan uygulamalara gelen interstitial ve etkileşimli geçiş (video) reklamlara yönelik tutum üzerinde en çok etkili olan faktörler; eğlence, güvenilirlik ve etkileşimliliktir. Benzer olarak; Raines (2013), Bhave vd. (2013) ve Hallgrimsson (2016)'un çalışmalarında uygulama içi mobil reklamlardan algılanan eğlence, güvenilirlik ve etkileşimlilik boyutlarının, reklamlara yönelik tutumlar üzerinde güçlü ve olumlu bir etkiye sahip oldukları tespit edilmiştir. Diğer taraftan rahatsız etme boyutu ise tutumları olumsuz 
etkilemektedir. Interstitial reklamlarda, kişiselleştirme boyutunun mobil reklama yönelik tutum üzerinde istatistiksel olarak anlamlı bir etkisinin olmadığı tespit edilmiştir. Etkileşimli geçiş (video) reklamlarında ise mesaj içeriğini oluşturan tüm boyutların, mobil reklama yönelik tutumu istatistiksel olarak anlamlı bir şekilde etkilediği tespit edilmiştir.

Interstitial reklam için içerik özelliklerinin, algılanan değer üzerindeki etkileri değerlendirildiğinde; tüketici açısından interstitial reklamı en çok değerli kılan özellikler eğlence ve güvenilirliktir. Merisavo vd. (2007), güvenilirliğin reklamı kabullenmenin güçlü bir belirleyicisi olduğunu tespit etmişlerdir. Tüketici, mesajı eğlenceli, doğru ve inanılır algıladığında mesajı daha değerli bulmaktadır. Etkileşimli geçiş (video) reklamı için içerik özelliklerinin, algılanan değer üzerindeki etkileri değerlendirildiğinde; tüketici açısından etkileşimli geçiş (video) reklamını en çok değerli kılan özellikler eğlence, güvenilirliğin yanında kişiselleştirme olmaktadır. Buna göre mesajın değerli algılanabilmesi için tüketicilerin istek ve ihtiyaçlarına, alışveriş sıklık ve alışkanlıklarına demografik özelliklerine ve ilgi alanlarına göre mesajın kişiselleştirilmesi gerekmektedir. Bu bulgular, Xu (2007) ile Demirgüneş ve Avcılar (2016) çalışmalarıyla benzerlik göstermektedir.

Üç reklam türü için genel olarak değerlendirildiğinde; mobil reklama yönelik tutum üzerinde etkili olan özellikler etkileşimlilik, eğlence ve güvenilirliktir. Algılanan değer üzerinde en etkili olan faktör ise mobil reklama yönelik tutumdur. Mobil reklama yönelik tutumun, algılanan değer üzerinde en yüksek etkiye sahip olduğu reklam türü, banner reklamlardır. Banner reklamlara yönelik tutumun olumlu olması, banner reklamların algılanan değerini artırmaktadır. Mobil reklam değerinin, mobil reklam kabulü üzerinde en yüksek etkiye sahip olduğu reklam türü ise etkileşimli geçiş (video) reklamlarıdır. Söz konusu özellikler güçlendirildiğinde, tüketiciler akıllı telefonlarında yer alan uygulamalara gelen banner, interstitial ve etkileşimli geçiş (video) reklam mesajlarını daha çok benimseyebileceklerdir. Bu özelliklerin yanı sıra reklam mesajı bilgi içerdiğinde ve daha az rahatsızlık verdiğinde, tutumlar olumlu yönde etkilenebilecek ve mobil reklam daha değerli olarak algılanabilecektir. Böylelikle tutum ve değer aracılığıyla tüketicilerin akıllı telefonlarında yer alan uygulamalara gelen mobil reklam mesajlarını kabul etmeleri sağlanabilecektir. Bu bulgulara göre reklam verenlere, reklam mesajlarını yaratıcı ve eğlendirici olarak tasarlamaları, animasyon, görsel sunumlar vb. özelliklere önem vermeleri, mesajın etkileşimli, doğru ve inanılır olmasına dikkat etmeleri önerilebilir.

Uygulama içi mobil reklamlar, pazarlamacılara tüketicileriyle iletişim kurmak için çok sayıda fırsat sunmaktadır. Facebook, Twitter, Google ve Pinterest gibi şirketler; gelirlerinin büyük bölümünü uygulama içi mobil reklamlardan elde etmektedirler. Mobil uygulama geliştiricilerinin yaklaşık yüzde $35^{\prime}$ inin gelir elde etmek için uygulama içi mobil reklamlara güvendiği tahmin edilmektedir (Wilcox, 2017). Ancak görüntülemeler ve tıklamalar karşılığında ödeme alabilmek için uygulamaların, etkileşimde bulunmaya istekli olan kullanıcılara ve reklamlara sahip olmaları gerekmektedir. Bu nedenle bu çalışmadan elde edilen bulgular, reklam verenler için uygulama içi mobil reklamların daha iyi anlaşılmasında önemli olmaktadır. Ayrıca bu araştırma, uygulama içi reklam alanında gelecekte yapılacak araştırmalar için de yol gösterici niteliktedir.

Bu çalışmanın en önemli kısıtı, analizlerin kolayda örnekleme yöntemi ile elde edilen verilerle gerçekleştirilmiş olmasıdır. Gelecekteki araştırmalar, tesadüfi örnekleme yöntemi kullanarak, farklı örneklem grupları üzerinde, farklı sosyo-demografik özelliklere, kültürel değerlere, kişilik özelliklerine sahip olan tüketicilerle gerçekleştirilebilir. Ayrıca bu çalışma, mobil uygulamalara gelen reklam türlerinin sadece üç tanesine yönelik olarak gerçekleştirilmiştir. Gelecekteki çalışmalar, reklam türlerinin tamamına yönelik olarak gerçekleştirilebilir. Ayrıca bu çalışma, sadece akıllı telefonlarda yer alan uygulamalara gelen mobil reklamlarla sınırlandırımıştır. Gelecekte yapılacak araştırmalarda araştırma modeli, farklı iletişim araçlarında (akıllı TV, tablet vb.) yer alan uygulamalara gelen mobil reklamlara yönelik tüketici tutumlarını değerlendirmek için kullanılabilir. 


\section{Kaynaklar}

Alwitt, L.F., \& Prabhaker, P.R. (1992). Function and belief dimensions of attitudes to television advertising: Implications for copy testing. Journal of Advertising Research, 32(5), 32-42.

Avery, K. (2016). Measuring consumers' willingness-to-pay to avoid disruptive advertising in smartphone applications. University of Colorado, Boulder CU Scholar, Undergraduate Honors Theses, USA.

Barnes, S. J. (2002). Wireless digital advertising: Nature and implications. International Journal of Advertising, 21(3), $399-420$.

Barutçu, S., \& Göl, M. Ö. (2009). Mobil reklamlar ve mobil reklam araçlarına yönelik tutumlar. KMU iiBF Dergisi, 11(17), 24-41.

Barwise, P., \& Strong, C. (2002). Permission- based mobile advertising. Journal of interactive Marketing, 16(1), $14-24$.

Bauer, H., Barnes, S., Reichardt, T., \& Neumann, M. M. (2005). Driving consumer acceptance of mobile marketing: A theoretical framework and empirical study. Journal of Electronic Commerce Research, 6(3), 181-192.

Bellman, S., Potter, R. F., Treleaven-Hassard, S., Robinson, J. A., \& Varan, D. (2011). The effectiveness of branded mobile phone apps. Journal of Interactive Marketing, 25(4), 191-200.

Bhave, K., Jain, V., \& Roy, S. (2013). Understanding the orientation of Gen Y toward mobile applications and in-app advertising in India. International Journal of Mobile Marketing, 8(1), 62-74.

Billore, A., \& Sadh, A. (2015). Mobile advertising: A review of the literature. The Marketing Review, 15(2), $161-183$.

Brackett, L. K., \& Carr, B. N. (2001). Cyberspace advertising vs. other media: Consumer vs. mature student attitudes. Journal of Advertising Research. 41(5), 23-33.

Carroll, A., Barnes, S. J., Scornavacca, E., \& Fletcher, K. (2007). Consumer perceptions and attitudes towards SMS advertising: Recent evidence from New Zealand. International Journal of Advertising, 26(1), 79-98.

Cheng, J.M., Blankson, C., Wang, E.S., \& Chen, L.S., (2009). Consumer attitudes and interactive digital advertising. International Journal of Advertising, 28(3), 501-525.

Choi, Y. K., Hwang, J. S., \& McMillan, S. J. (2008). Gearing up for mobile advertising: A cross-cultural examination of key factors that drive mobile messages home to consumers. Psychology \& Marketing, 25(8), 756-768.

Chowdhury, H. K., Parvin, N., Weitenberner, C., \& Becker, M. (2006). Consumer attitude toward mobile advertising in an emerging market: An empirical study. International Journal of Mobile Marketing, 1(2),33-42.

Constantinescu, L. M., \& Tanasescu, I. (2014). Online advertising: An informational \& communication space for the enterprise. Annales Universitatis Apulensis: Series Oeconomica, 16(1), 76-84.

Demirgüneş, B. K., \& Avcılar, M. Y. (2016, October). Mobil reklam değeri ve akış deneyiminin, mobil reklamları kabullenme üzerindeki etkileri. 21. Pazarlama Kongresi: Dijital Dünyada Pazarlama.

Ducoffe, R. H. (1996). Advertising value and advertising on the web. Journal of Advertising Research, 36(5), 21-35.

Fleit B. (2017). Pros ve cons of 5 mobile ad options. http://blog.kiip.me/developers/mobile-ad-options, (Erişim Tarihi, 5 Temmuz 2017).

Haghirian, P., Madlberger, M., \& Inoue, A. (2008 January). Mobile advertising in different stages of development: A cross-country comparison of consumer attitudes. Proceedings of the Proceedings of the 41st Annual Hawaii International Conference on System Sciences.

Haghirian, P., Madlberger, M., \& Tanuskova, A. (2005, January). Increasing advertising value of mobile marketing- an empirical study of antecedents. Proceedings of the 38th Annual Hawaii International Conference on System Sciences.

Hair, J. F., Rolp, E. A., Ronald, L. T., \& William, C. B. (1998). Multivariate data analysis (International Fifth Edition). USA: Prentice Hall.

Hallgrímsson, A. G. (2016). Factors affecting attitudes and behavioral intentions towards in- app mobile advertisements: A cross-cultural comparison between India and the United Kingdom. Reykjavik University/ School of Business, Master's Thesis, Iceland.

Hoffman, D. L., \& Novak, T.P. (1996). Marketing in hypermedia computer-mediated environments: Conceptual foundations. Journal of Marketing, 60, 50 - 68.

Jun, J., \& Lee, S. (2007). Mobile media use and its impact on consumer attitudes toward mobile advertising. International Journal of Mobile Marketing, 2(1), 50-58. 
Kim, Y. J., \& Han, J., (2014). Why smartphone advertising attracts customers: A model of web advertising, flow, and personalization. Computers in Human Behavior, 33, 256-269

Kurtuluş, K. (2004). Pazarlama araştırmaları (8. Baskı). İstanbul: Literatür Yayıncılık.

Lee, C. C., \& Hsieh, M. C. (2009). The influence of mobile self-efficacy on attitude towards mobile advertising. International Conference on New Trends in Information and Service Science.

Li, H., \& Stoller, B. (2007). Parameters of mobile advertising a field experiment. International Journal of Mobile Marketing, 2(1), 4-11.

Liu, C. L. E., Sinkovics, R. R., Pezderka, N., \& Haghirian, P. (2012). Determinants of consumer perceptions toward mobile advertising: A comparison between Japan and Austria. Journal of Interactive Marketing, 26(1), 21-32.

Liu, Y. (2003). Developing a scale to measure the interactivity of websites. Journal of Advertising Research, 43(2), 207-216.

MacKenzie, S. B., \& Lutz, R. J. (1989). An empirical examination of the structural antecedents of attitude toward the Ad in an advertising pretesting context. Journal of Marketing, 53, 48-65.

Melton, M. (2017). Comparing responses to In-App and mobile web Ads. https://www.emarketer.com (Erişim Tarihi, 5 Temmuz 2017).

Merisavo, M., Kajalo, S., Karjaluoto, H., Virtanen, V., Salmenkivi, S., Raulas, M., \& Leppäniemi, M. (2007). An empirical study of the drivers of consumer acceptance of mobile advertising. Journal of Interactive Advertising, 7(2), 4150.

Moynihan, B., Kabadayi, S., \& Kaiser, M. (2010). Consumer acceptance of SMS advertising: A study of American and Turkish consumers. International Journal of Mobile Communications, 8(4), 392-410.

Nabus, H. S. Y., \& Hussin, A. R. C. (2015). Identifying factors affecting mobile advertising based on consumer attitude. Journal of Information Systems Research and Innovation, 9(2), 1-8.

Nakip, M. (2003). Pazarlama araştırmaları teknikler ve (SPSS Destekli) uygulamalar. Ankara: Seçkin Yayıncılık.

Nielsen (2013). The mobile consumer: A global snapshot. http://www.nielsen.com/content/dam/corporate/us/en/reportsdownloads/2013\%20Reports/MobileConsumer-Report-2013.pdf (Erişim Tarihi, 06 Temmuz 2017).

Novak, T.P., \& Hoffman, D.L. (2000). Advertising and pricing models for the web. (Ed.) Deborah Hurley, Brian Kahin \& Hal Varian, in Internet publishing and beyond: The economics of digital information and intellectual property (ss. 1-22). Cambridge: MIT Press.

Okazaki, S. (2004). How do Japanese consumers perceive wireless ads? A multivariate analysis. International Journal of Advertising, 23(4), 429-454.

Okozaki, S, Katsura, A., \& Nishiyama, M. (2007). How mobile advertising works: The role of trust in improving attitudes and recall. Journal of Advertising Research, 47(2), 165-178.

Park, T., Shenoy, R., \& Salvendy, G. (2008). Effective advertising on mobile phones: A literature review and presentation of results from 53 case studies. Behaviour and Information Technology, 27(5), 355-373.

Parreño, J. M., Sanz-Blas, S., Ruiz-Mafé, C., \& Aldás-Manzano, J. (2013). Key factors of teenagers' mobile advertising acceptance. Industrial Management and Data Systems, 113(5), 732-749.

Persaud, A., \& Azhar, I. (2012). Innovative mobile marketing via smartphone: Are consumers ready?. Marketing Intelligence and Planning, 30 (4), 418-443.

Rabiei, M., Ganji, A., \& Shamsi M. (2012). Mobile advertising acceptance model: Evaluation of key factors in Iran. MiddleEast Journal of Scientific Research, 11(6), 740-747.

Raines, C. (2013). In-app mobile advertising: Investigating consumer attitudes towards pull-based mobile advertising amongst young adults in the UK. Journal of Promotional Communications, 1(1), 125-148.

Reklamcılar Derneği (2017). Türkiye Medya Yatııımları. Http://rd.org.tr/doc/RD_TABLO_2017_MART.pdf. (Erişim Tarihi, 1 Temmuz 2017).

Rojas-Mendez, J. I., Davies, G., \& Madran, C. (2009). Universal differences in advertising avoidance behavior: A crosscultural study. Journal of Business Research, 62, 947-954.

Saadeghvaziri, F., \& Hosseini, H. K. (2011). Mobile advertising: An investigation of factors creating positive attitude in Iranian customers. African Journal of Business Management, 5(2), 394-404.

Sabokwigina, D., Malima, G., \& Mpogole, H. (2013, May). SMS advertising in Tanzania: Factors affecting consumer attitudes. IST-Africa 2013 Conference \& Exhibition. 
Sandage, C.H., Fryburger, V., \& Rotzoll K. (1989). Advertising, theory and practice. New York: Longman Inc, 1989.

Scharl, A., Dickinger, A., \& Murphy, J. (2005). Diffusion and success factors of mobile marketing. Electronic Commerce Research and Applications, 4(2), 159-173.

Schlosser, A.E., Shavitt, S., \& Kanfer, A. (1999). Survey of internet users' attitudes toward internet advertising. Journal of Interactive Marketing, 13 (3), 34-54.

Social \& Hootsuite (2017). Digital in 2017: Global Overview. https://wearesocial.com/specialreports/digital-in-2017global-overview (Erişim Tarihi, 01 Temmuz 2017).

Tabachnick, B. G., \& Fidell, L. S. Using multivariate statistics. Boston: Pearson Education.

Ting, H., De Run, E. C., \& Thurasamy, R. (2015). Young adults' attitude towards advertising: A multi-group analysis by ethnicity. Revista Brasileira de Gestão de Negócios, 17(54), 769-787.

Tsang, M. M., Ho, S.C., \& Liang, T.P. (2004). Consumer attitudes toward mobile advertising: An empirical study. International Journal of Electronic Commerce, 8(3), 65-78

Türkiye İstatistik Kurumu (2016). Hane halkı bilişim teknolojileri kullanım araştırması, 2016. http://www.tuik.gov.tr/PreHaberBultenleri.do?id=21779. (Erişim Tarihi, 1 Temmuz 2017).

Ünal, S., Ercis, A., \& Keser, E. (2011). Attitudes towards mobile advertising-A research to determine the differences between the attitudes of youth and adults. Procedia-Social and Behavioral Sciences, 24, 361-377.

Unni, R., \& Harmon, R. (2007). Perceived effectiveness of push vs. pull mobile location-based advertising. Journal of Interactive advertising, 7(2), 28-40.

Valvi, A. C., \& West, D. C. (2015). Mobile applications (Apps) in advertising: A grounded theory of effective uses and practices. In Ideas in Marketing: Finding the New and Polishing the Old. Springer International Publishing, 349352.

Watkins, J., Hjorth, L. \& Koskinen, I. (2012). Wising up: Revising mobile media in an age of smartphone. Journal of Media \& Cultural Studies, 26(5), 665-668.

Watson, C., McCarthy, J., \& Rowley, J. (2013). Consumer attitudes towards mobile marketing in the smart phone era. International Journal of Information Management, 33(5), 840-849.

Westerlund, M., Rajala, R., Tuunanen, T., \& Salo, J. (2009). The influence of content and trust on consumers' intention to accept mobile advertisements. International Journal of E-service and Mobile Applications, 1(4), 1-15.

Wilcox, M. (2014). Building a business not just an app? Start with the revenue model. https://www.developereconomics.com. (Erişim Tarihi, 30 Haziran 2017).

Wong, M. M. T., \& Tang, E. P. Y. (2008). Consumers' attitudes towards mobile advertising: The role of permission. Review of Business Research, 8 (3).

$\mathrm{Xu}, \mathrm{D}$. (2007). The Influence of personalization in affecting consumer attitude toward mobile advertising in China. The Journal of Computer Information Systems, 47 (2), 9-19.

Yan, Z. (2006). What influences children's and adolescents' understanding of the complexity of the internet?. Developmental Psychology, 42(3).

Yang, B., Kim, Y., \& Yoo, C. (2013). The integrated mobile advertising model: The effects of technology- and emotionbased evaluations. Journal of Business Research, 66(9), 1345-1352.

Yang, Kenneth C.C. (2007). Exploring factors affecting consumer intention to use mobile advertising in Taiwan. Journal of International Consumer Marketing, 20(1), 33-49.

Yücel Y. (2012). Mobil uygulaması olan bir işletme misiniz? Arama ağı reklamlarından daha iyi faydalanın. https://adwordstr.googleblog.com. (Erişim Tarihi, 05 Temmuz 2017).

Zabadi, A. M. A., Shura, M., \& Elsayed, E. A. (2012). Consumer attitudes toward SMS advertising among Jordanian users. International Journal of Marketing Studies, 4(1), 77-94. 


\section{Ekler}

Ek 1. Cevaplayıcıların Demografik Özellikleri ve Tanımlayııı İstatistikler

\begin{tabular}{|c|c|c|c|c|c|}
\hline Cinsiyet & $\begin{array}{l}\text { Frekans } \\
(\mathrm{N}=550)\end{array}$ & $\begin{array}{l}\text { Yüzde } \\
\text { (\%) }\end{array}$ & Medeni Durum & $\begin{array}{l}\text { Frekans } \\
(\mathrm{N}=550)\end{array}$ & $\begin{array}{l}\text { Yüzde } \\
\text { (\%) }\end{array}$ \\
\hline Kadın & 263 & 48 & Evli & 326 & 59 \\
\hline Erkek & 287 & 52 & Bekar & 224 & 41 \\
\hline Yaş & $\mathbf{N}$ & $\%$ & Eğitim Düzeyi & $\mathbf{N}$ & $\%$ \\
\hline $18-25$ & 56 & 10 & ilkokul & 17 & 3 \\
\hline $26-35$ & 215 & 39 & Lise & 95 & 17 \\
\hline $36-45$ & 143 & 26 & Lisans & 352 & 64 \\
\hline $46-55$ & 95 & 17 & Yüksek Lisans & 75 & 14 \\
\hline $56-65$ & 44 & 8 & Doktora & 11 & 2 \\
\hline Meslek & $\mathbf{N}$ & $\%$ & Aylık Gelir Düzeyi (TL) & $\mathbf{N}$ & $\%$ \\
\hline Ev Hanımı & 15 & 3 & 1.409 TL'den az & 48 & 8 \\
\hline İşçi & 59 & 11 & $1410-3.000$ & 121 & 22 \\
\hline Memur & 374 & 67 & $3.001-4.600$ & 323 & 59 \\
\hline Emekli & 12 & 2 & $4.601-6.200$ & 41 & 8 \\
\hline Esnaf & 3 & 1 & $6.201-7.800$ & 5 & 1 \\
\hline Öğrenci & 36 & 7 & 7801 TL'den fazla & 12 & 2 \\
\hline Serbest Meslek & 5 & 1 & Mobil Reklamlara Yönelik Davranış & $\mathbf{N}$ & $\%$ \\
\hline Diğer & 46 & 8 & Hemen okurum & 24 & 4 \\
\hline $\begin{array}{l}\text { Mobil Reklam Kaynağı } \\
\text { (İşletme Türü) }\end{array}$ & $\mathbf{N}$ & $\%$ & Vakit bulunca sonra okurum & 271 & 49 \\
\hline Banka & 123 & 22 & $\begin{array}{l}\text { Mesajın kaynağına bağlı olarak } \\
\text { sonra okurum }\end{array}$ & 136 & 25 \\
\hline Gıda Marketleri & 30 & 6 & $\begin{array}{l}\text { Mesajın içeriğine bağlı olarak sonra } \\
\text { okurum }\end{array}$ & 119 & 22 \\
\hline Giyim Mağazaları & 185 & 34 & Sık Gelen Mobil Reklam Türü & $\mathbf{N}$ & $\%$ \\
\hline Mobil Oyunlar & 95 & 17 & Banner & 158 & 29 \\
\hline Teknoloji Mağazaları & 86 & 16 & Interstitial & 101 & 18 \\
\hline $\begin{array}{l}\text { Operatör Hizmeti Satış } \\
\text { Mağazaları }\end{array}$ & 31 & 5 & Etkileşimli Geçiş Reklamları & 80 & 15 \\
\hline Mobil Reklam Tercihi & $\mathbf{N}$ & $\%$ & Etkileşimli Video Reklamları & 106 & 19 \\
\hline Banner & 161 & 29 & Tıkla İndir Uygulama Reklamları & 105 & 19 \\
\hline Interstitial & 93 & 16 & $\begin{array}{l}\text { Alınan Mobil Reklam Sayısı / Banner } \\
\text { (Ortalama/Gün) }\end{array}$ & $\mathbf{N}$ & $\%$ \\
\hline Etkileşimli Geçiş Reklamları & 91 & 17 & Hiç & 121 & 22 \\
\hline Etk. Video Reklamları & 119 & 22 & $1-3$ & 253 & 46 \\
\hline $\begin{array}{l}\text { Tıkla İndir Uygulama } \\
\text { Reklamları }\end{array}$ & 86 & 16 & $4-5$ & 141 & 26 \\
\hline $\begin{array}{l}\text { Alınan Mobil Reklam Sayısı / } \\
\text { İnterstitial(Ortalama/Gün) }\end{array}$ & $\mathbf{N}$ & $\%$ & 6 ve daha fazlası & 35 & 6 \\
\hline Hiç & 118 & 22 & $\begin{array}{l}\text { Alınan Mobil Reklam Sayısı / } \\
\text { Etkileşimli Geçiş (Ortalama/Gün) }\end{array}$ & $\mathbf{N}$ & $\%$ \\
\hline $1-3$ & 297 & 54 & Hiç & 132 & 24 \\
\hline $4-5$ & 107 & 19 & $1-3$ & 277 & 50 \\
\hline 6 ve daha fazlası & 28 & 5 & $4-5$ & 109 & 20 \\
\hline $\begin{array}{l}\text { Alınan Mobil Reklam Sayısı / } \\
\text { Etkileşimli } \\
\text { (Ortalama/Gün) }\end{array}$ & $\mathbf{N}$ & $\%$ & 6 ve daha fazlası & 32 & 6 \\
\hline Hiç & 105 & 19 & $\begin{array}{l}\text { Alınan Mobil Reklam Sayısı / Tıkla } \\
\text { İndir (Ortalama/Gün }\end{array}$ & $\mathbf{N}$ & $\%$ \\
\hline $1-3$ & 286 & 52 & Hiç & 123 & 22 \\
\hline $4-5$ & 117 & 21 & $1-3$ & 282 & 51 \\
\hline \multirow{2}{*}{6 ve daha fazlası } & \multirow{2}{*}{42} & \multirow{2}{*}{8} & $4-5$ & 122 & 22 \\
\hline & & & 6 ve daha fazlası & 23 & 5 \\
\hline
\end{tabular}




\section{Ek 2. Keşifsel Faktör Analizi Sonuçları}

\begin{tabular}{|c|c|c|c|c|c|c|c|c|}
\hline : & 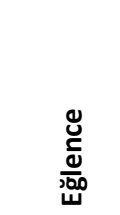 & 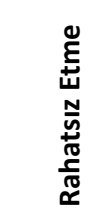 & 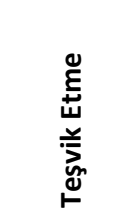 & 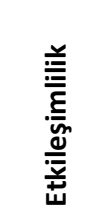 & 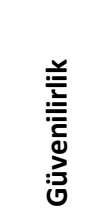 & 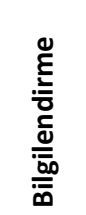 & 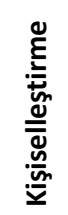 & 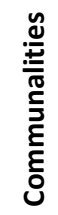 \\
\hline EGL3 & ,884 & & & & & & & ,923 \\
\hline EGL2 &, 869 & & & & & & & ,909 \\
\hline EGL7 & 839 & & & & & & & 831 \\
\hline EGL5 & 832 & & & & & & & 872 \\
\hline EGL1 & 829 & & & & & & & 844 \\
\hline EGL6 & 817 & & & & & & & ,782 \\
\hline EGL4 & ,758 & & & & & & & ,792 \\
\hline RE3 & & ,928 & & & & & &, 841 \\
\hline RE2 & & ,912 & & & & & & 887 \\
\hline RE4 & & 896 & & & & & & 897 \\
\hline RE6 & & 893 & & & & & &, 823 \\
\hline RE1 & & 889 & & & & & & ,777 \\
\hline RE5 & & 861 & & & & & &, 829 \\
\hline TE3 & & & ,813 & & & & & 831 \\
\hline TE4 & & & 808 & & & & &, 811 \\
\hline TE2 & & & ,772 & & & & & ,796 \\
\hline TE5 & & & ,735 & & & & & ,772 \\
\hline TE6 & & & 687 & & & & &, 654 \\
\hline TE1 & & & 643 & & & & & ,662 \\
\hline ETK5 & & & &, 756 & & & & ,792 \\
\hline ETK3 & & & &, 753 & & & & 820 \\
\hline ETK6 & & & & ,742 & & & & ,780 \\
\hline ETK4 & & & & ,738 & & & & ,692 \\
\hline ETK2 & & & & ,721 & & & & ,768 \\
\hline ETK1 & & & & 687 & & & & ,736 \\
\hline GUV2 & & & & & ,803 & & & 831 \\
\hline GUV1 & & & & & ,795 & & & ,791 \\
\hline GUV3 & & & & & ,759 & & & 817 \\
\hline GUV5 & & & & & 720 & & & ,725 \\
\hline GUV6 & & & & & ,687 & & &, 633 \\
\hline GUV4 & & & & & 655 & & & ,698 \\
\hline BíL5 & & & & & & ,812 & & ,794 \\
\hline BIL3 & & & & & & ,794 & &, 815 \\
\hline BIL4 & & & & & & ,790 & & ,769 \\
\hline BíL1 & & & & & &, 758 & & ,721 \\
\hline BíL2 & & & & & & ,757 & &, 765 \\
\hline kis5 & & & & & & & 816 & ,783 \\
\hline kis3 & & & & & & & 808 & ,784 \\
\hline Kis1 & & & & & & & ,744 & ,777 \\
\hline Kis4 & & & & & & & 694 & 651 \\
\hline Kis2 & & & & & & & ,693 & ,741 \\
\hline Öz Değer & 5,100 & 4,450 & 4,370 & 3,766 & 4,388 & 6,024 & 4,096 & \\
\hline Açıklanan Varyans \% & 12,438 & 10,853 & 10,658 & 9,185 & 10,702 & 14,693 & 9,991 & \\
\hline Top. Açık. Var. \% & 78,519 & & & & & & & \\
\hline Cronbach's Alfa & ,949 & ,939 & ,930 & ,936 & ,928 & ,927 & 900 & \\
\hline Toplam Cronbach's Alfa & 0,945 & & & & & & & \\
\hline $\mathrm{KMO}$ & 947 & & & & & & & \\
\hline Barlett Test & $\begin{array}{c}23895 \\
P=0.000\end{array}$ & & & & & & & \\
\hline Faktör Ağırlıkları & $>.45$ & & & & & & & \\
\hline
\end{tabular}

Not: Faktörleştirme Yöntemi (Temel Bileşen Analizi); Rotasyon Yöntemi (Kaiser Normalleştirme İle Varimax) EGL=Eğlence; RE=Rahatsız Etme; $\mathrm{TE}=$ Teşvik Etme; ETK=Etkileşimlilik; GUV=Güvenilirlik; BIL=Bilgilendirme; KIS=Kişiselleştirme 
M. Y. Avcilar - B. Kulter-Demirgunes - G. Yenilmez

Ek 3. Banner Reklam İçin Hiyerarşik Regresyon Analizi Sonuçları

\begin{tabular}{|c|c|c|c|c|c|c|c|c|c|}
\hline Değişkenler & Stand. $\beta$ & $t$ - değeri & $P$ & $s r^{2}$ & $R^{2}$ & $\Delta R^{2}$ & $F$ & $\Delta F$ & Sig. $\Delta F$ \\
\hline \multicolumn{10}{|l|}{ 1. Aşama } \\
\hline $\begin{array}{l}\text { Bağımlı Değişken: Tutum } \\
\text { Bağımsız Değişkenler: }\end{array}$ & & & & & ,392 & ,392 & 49,84 & 49,84 &, $000 * * *$ \\
\hline Bilgilendirme & ,067 & 2,439 &, $015^{* *}$ & 0.00 & & & & & \\
\hline Eğlence & ,181 & 3,980 &, $000 * * *$ & 0.02 & & & & & \\
\hline Rahatsız Etme &,- 114 & $-3,160$ &, $002 * * *$ & 0.01 & & & & & \\
\hline Güvenilirlik & 144 & 2,803 &, $005^{* * *}$ & 0.01 & & & & & \\
\hline Teşvik Etme & ,060 & 1,172 & ,242 & 0.00 & & & & & \\
\hline Kişiselleştirme & ,029 & ,554 &, 580 & 0.00 & & & & & \\
\hline Etkileşimlilik & ,252 & 4,651 &, $000 * * *$ & 0.02 & & & & & \\
\hline \multicolumn{10}{|l|}{ 2. Aşama } \\
\hline $\begin{array}{l}\text { Bağımlı Değişken: Mobil } \\
\text { Reklam Değeri } \\
\text { Bağımsız Değişkenler: }\end{array}$ & & & & & ,504 & 112 & 68,62 & 122,13 &, $000 * * *$ \\
\hline Bilgilendirme & ,071 & 2,744 &, $006 * * *$ & 0.00 & & & & & \\
\hline Eğlence & ,082 & 2,973 &, $002 * * *$ & 0.00 & & & & & \\
\hline Rahatsız Etme &,- 030 &,- 880 & ,379 & 0.00 & & & & & \\
\hline Güvenilirlik & ,002 & ,045 & ,964 & 0.00 & & & & & \\
\hline Teşvik Etme & ,017 & ,365 & ,715 & 0.00 & & & & & \\
\hline Kişiselleştirme & ,026 & ,554 &, 580 & 0.00 & & & & & \\
\hline Etkileşimlilik & ,037 & ,702 &, 483 & 0.00 & & & & & \\
\hline Tutum & ,554 & 11,051 &, $000 * * *$ & 0.11 & & & & & \\
\hline \multicolumn{10}{|l|}{ 3. Aşama } \\
\hline $\begin{array}{l}\text { Bağımlı Değişken: Mobil } \\
\text { Reklam Kabulü } \\
\text { Bağımsız Değişkenler: }\end{array}$ & & & & & ,597 & ,093 & 88,79 & 124,64 &, $000 * * *$ \\
\hline Bilgilendirme & ,047 & 2,286 &, $022^{*}$ & 0.00 & & & & & \\
\hline Eğlence & ,066 & 1,736 &, $083^{*}$ & 0.00 & & & & & \\
\hline Rahatsız Etme &,- 015 &,- 489 & ,625 & 0.00 & & & & & \\
\hline Güvenilirlik & ,003 & ,073 & 942 & 0.00 & & & & & \\
\hline Teşvik Etme &,- 032 &,- 774 & ,439 & 0.00 & & & & & \\
\hline Kişiselleştirme & ,007 & 170 &, 865 & 0.00 & & & & & \\
\hline Etkileşimlilik & 036 & ,760 & ,448 & 0.00 & & & & & \\
\hline Tutum & ,249 & 4,726 &, $000 * * *$ & 0.02 & & & & & \\
\hline Mobil Reklam Değeri & ,483 & 11,164 &, $000 * * *$ & 0.09 & & & & & \\
\hline
\end{tabular}

Not: $\mathrm{N}=550{ }^{*}: \mathrm{p}<.10 ;{ }^{* *}: \mathrm{p}<.05{ }^{* * *}: \mathrm{p}<.01$ 
Ek 4. Interstitial (Tam Sayfa) Reklam İçin Hiyerarşik Regresyon Analizi Sonuçları

\begin{tabular}{|c|c|c|c|c|c|c|c|c|c|}
\hline Değişkenler & Stand. $\beta$ & t- değeri & $P$ & $s r^{2}$ & $R^{2}$ & $\Delta R^{2}$ & $F$ & $\Delta F$ & Sig. $\Delta F$ \\
\hline \multicolumn{10}{|l|}{ 1. Aşama } \\
\hline $\begin{array}{l}\text { Bağımlı Değişken: Tutum } \\
\text { Bağımsız Değişkenler: }\end{array}$ & & & & & $\begin{array}{l}\text {,41 } \\
0\end{array}$ & $\begin{array}{l}41 \\
0\end{array}$ & 53,797 & $\begin{array}{l}53,79 \\
7\end{array}$ &, $000 * * *$ \\
\hline Bilgilendirme & ,044 & 2,990 &, $003^{* * *}$ & 0.00 & & & & & \\
\hline Eğlence & ,177 & 3,965 &, $000 * * *$ & 0.02 & & & & & \\
\hline Rahatsız Etme &,- 151 & $-4,241$ &, $000 * * *$ & 0.02 & & & & & \\
\hline Güvenilirlik & ,199 & 3,948 &, $000 * * *$ & 0.02 & & & & & \\
\hline Teşvik Etme & 086 & 1,722 & $086^{*}$ & 0.00 & & & & & \\
\hline Kişiselleştirme & ,076 & 1,469 & 142 & 0.00 & & & & & \\
\hline Etkileşimlilik & ,155 & 2,905 &, $004 * * *$ & 0.01 & & & & & \\
\hline \multicolumn{10}{|l|}{ 2. Aşama } \\
\hline $\begin{array}{l}\text { Bağımlı Değişken: Mobil } \\
\text { Reklam Değeri } \\
\text { Bağımsız Değişkenler: }\end{array}$ & & & & & $\begin{array}{l}, 48 \\
7\end{array}$ & , 077 & 64,105 & 80,806 &, $000 * * *$ \\
\hline Bilgilendirme & , 047 & 2,136 & ,033** & 0.00 & & & & & \\
\hline Eglence & 095 & 2,231 & $026 * *$ & 0.00 & & & & & \\
\hline Rahatsız Etme &,- 081 & $-2,371$ & $018^{* *}$ & 0.01 & & & & & \\
\hline Güvenilirlik & 082 & 1,682 & ,093* & 0.00 & & & & & \\
\hline Teşvik Etme & 051 & 1,084 & 279 & 0.00 & & & & & \\
\hline Kişiselleştirme & ,074 & 1,526 & 128 & 0.00 & & & & & \\
\hline Etkileşimlilik &,- 023 &,- 426 & 670 & 0.00 & & & & & \\
\hline Tutum & ,458 & 8,989 &, $000 * * *$ & 0.08 & & & & & \\
\hline \multicolumn{10}{|l|}{ 3. Aşama } \\
\hline $\begin{array}{l}\text { Bağımlı Değişken: Mobil } \\
\text { Reklam Kabulü } \\
\text { Bağımsız Değişkenler: }\end{array}$ & & & & & $\begin{array}{l}, 68 \\
2\end{array}$ & 196 & 128,937 & 332,939 &, $000 * * *$ \\
\hline Bilgilendirme & ,039 & 2,287 & ,022* & 0.00 & & & & & \\
\hline Eğlence & 028 & 2,824 &, $004^{* * *}$ & 0.00 & & & & & \\
\hline Rahatsız Etme &,- 006 &,- 207 & 836 & 0.00 & & & & & \\
\hline Güvenilirlik &, 022 &, 558 &, 577 & 0.00 & & & & & \\
\hline Teşvik Etme &, 034 & ,916 & 360 & 0.00 & & & & & \\
\hline Kişiselleştirme & 001 & 014 & 989 & 0.00 & & & & & \\
\hline Etkileşimlilik &,- 004 &,- 091 & 927 & 0.00 & & & & & \\
\hline Tutum & ,169 & 3,908 &, $000 * * *$ & 0.01 & & & & & \\
\hline Mobil Reklam Değeri & ,647 & $\begin{array}{l}18,24 \\
7\end{array}$ &, $000 * * *$ & 0.20 & & & & & \\
\hline
\end{tabular}

Not: $N=550 ;{ }^{*}: p<.10 ;{ }^{* *}: p<.05 ;{ }^{* * *}: p<.01$ 
M. Y. Avcilar - B. Kulter-Demirgunes - G. Yenilmez

Ek 5. Etkileşimli Geçiş (Video) Reklam İçin Hiyerarşik Regresyon Analizi Sonuçları

\begin{tabular}{|c|c|c|c|c|c|c|c|c|c|}
\hline Değişkenler & Stand. $\beta$ & $t$ - değeri & $P$ & $s r^{2}$ & $R^{2}$ & $\Delta R^{2}$ & $F$ & $\Delta F$ & Sig. $\Delta F$ \\
\hline \multicolumn{10}{|l|}{ 1. Aşama } \\
\hline $\begin{array}{l}\text { Bağımlı Değişken: } \\
\text { Tutum } \\
\text { Bağımsız Değişkenler: }\end{array}$ & & & & & ,436 & ,436 & 59,938 & 59,938 &, $000 * * *$ \\
\hline Bilgilendirme & 072 & 2,335 & ,019** & 0.00 & & & & & \\
\hline Eğlence & ,231 & 5,274 &, $000 * * *$ & 0.03 & & & & & \\
\hline Rahatsız Etme &,- 142 & $-4,084$ &, $000^{* * *}$ & 0.02 & & & & & \\
\hline Güvenilirlik & 205 & 4,146 &, $000^{* * *}$ & 0.02 & & & & & \\
\hline Teşvik Etme & 108 & 2,192 & ,029* & 0.01 & & & & & \\
\hline Kişiselleştirme & 085 & 2,670 & ,017* & 0.00 & & & & & \\
\hline Etkileşimlilik & ,148 & 2,834 &, $005^{* * *}$ & 0.01 & & & & & \\
\hline \multicolumn{10}{|l|}{ 2. Aşama } \\
\hline $\begin{array}{l}\text { Bağımlı Değişken: } \\
\text { Mobil Reklam Değeri } \\
\text { Bağımsız Değişkenler: }\end{array}$ & & & & &, 520 & ,084 & 73,344 & 94,673 &, $000 * * *$ \\
\hline Bilgilendirme & ,044 & 2,281 & ,023** & 0.00 & & & & & \\
\hline Eğlence & ,145 & 3,504 &, $000 * * *$ & 0.01 & & & & & \\
\hline Rahatsız Etme &,- 069 & $-2,084$ &, $038^{* *}$ & 0.00 & & & & & \\
\hline Güvenilirlik & 082 & 1,736 &, $083^{*}$ & 0.00 & & & & & \\
\hline Teşvik Etme &, 070 & 1,550 & ,122 & 0.00 & & & & & \\
\hline Kişiselleştirme & 082 & 1,757 & ,079* & 0.00 & & & & & \\
\hline Etkileşimlilik &,- 038 &,- 740 & 460 & 0.00 & & & & & \\
\hline Tutum & 479 & 9,730 &, $000 * * *$ & 0.08 & & & & & \\
\hline \multicolumn{10}{|l|}{ 3. Aşama } \\
\hline $\begin{array}{l}\text { Bağımlı Değişken: } \\
\text { Mobil Reklam Kabulü } \\
\text { Bağımsız Değişkenler: }\end{array}$ & & & & & ,727 & 207 & 159,889 & 409,357 &, $000^{* * *}$ \\
\hline Bilgilendirme & ,035 & $-2,173$ &, $030 * *$ & 0.00 & & & & & \\
\hline Eğlence & 079 & 2,522 &, $012^{* *}$ & 0.00 & & & & & \\
\hline Rahatsız Etme &,- 024 &,- 955 & 340 & 0.00 & & & & & \\
\hline Güvenilirlik & 107 & 3,006 &, $003^{* * *}$ & 0.00 & & & & & \\
\hline Teşvik Etme & 012 & 347 &, 729 & 0.00 & & & & & \\
\hline Kişiselleştirme &, 025 & ,719 & ,472 & 0.00 & & & & & \\
\hline Etkileşimlilik &,- 039 & $-1,003$ & 317 & 0.00 & & & & & \\
\hline Tutum & ,144 & 3,525 &, $000 * * *$ & 0.01 & & & & & \\
\hline Mobil Reklam Değeri & 663 & 20,233 &, $000 * * *$ & 0.21 & & & & & \\
\hline
\end{tabular}

Not: $N=550 ; *: p<.10 ;{ }^{* *}: p<.05 ;^{* * *}: p<.01$ 
This Page Intentionally Left Blank 